\title{
A conceptual geological model for offshore wind sites in palaeo ice stream settings: The Utsira Nord site, North Sea
}

\author{
A geological model for Utsira Nord \\ Hannah E. Petrie ${ }^{1 *}$, Christian H. Eide ${ }^{1}$, Haflidi Haflidason ${ }^{1}$ \& Timothy Watton ${ }^{2}$ \\ ${ }^{1}$ University of Bergen, Department of Earth Science, Allégaten 41, 5007 Bergen, Norway \\ 2 Equinor Energy ASA, PB 8500, 4035 Stavanger, Norway \\ *Corresponding author: hannah.petrie@uib.no (Twitter @NorthSeaPetrie)
}

We welcome your feedback on this research. Feel free to contact the corresponding author via email (hannah.petrie@uib.no). This is a non-peer-reviewed pre-print. Subsequent versions of this manuscript may include revisions based on feedback and the peer-review process. If accepted in a peer-reviewed journal, the post-review version of this manuscript will be available via the "Peerreviewed Publication DOI" link on the EarthArXiv page for this paper. 
While much work has been done to advance our understanding of the Quaternary geology of the Norwegian North Sea (e.g., Sejrup et al. 1994, 1995, 2000, 2003, 2016; Haflidason et al. 1998; Nygård et al. 2005; Lekens et al. 2009; Ottesen et al. 2016; Morén et al. 2018), the application of this knowledge towards floating offshore wind technology is still a relatively new field of study. Compared with offshore oil and gas installations, offshore wind turbines require a different set of geotechnical design considerations. On offshore wind farms, turbines are installed in greater numbers, cover much larger areas and are subjected to different loads by the wind and waves (Le et al. 2014; Ellery and Comrie, 2019). This means that further work on the specific interactions between offshore wind anchors and the soil into which they are embedded is urgently required as part of the targeted research into mooring solutions recommended by Wind Europe (2018) to reduce the cost of FOW. A detailed geological understanding of the foundation and anchoring conditions within new market areas will be an important component of this area of research (Velenturf et al. 2021).

While design methods and procedures for offshore wind infrastructure continue to develop and improve, the learning process for geotechnical site investigation for offshore wind has often been hampered by lack of a "design-team-led" approach to planning, undertaking, and reviewing site investigations (Muir Wood and Knight, 2013). This has led to problems such as site surveys being carried out with insufficient understanding of the geological setting, which are not tailored to mitigate the site-specific geotechnical hazards. Other site surveys did not meet the requirements of the foundation designers, who were brought in too late in the development process to influence the survey scope.

The Norwegian North Sea is a new market area for the development of offshore wind but is already a mature oil and gas province with publicly available 2D and 3D seismic datasets. With such abundant subsurface data, often lacking in new offshore wind areas, present and future offshore wind projects within the Norwegian North Sea could have a strong advantage over other market areas in terms of giving developers the ability to develop a conceptual 3D geological understanding of the survey area in the early phases of the project. The two Norwegian sites (both covering areas $>1000 \mathrm{~km}^{2}$ ) were officially open to bids as of the beginning of 2021, although the bidding process remains in development. The subject of this study is the Utsira Nord site (Fig. 1), located $30 \mathrm{~km}$ off the western coast of Norway in the c. $270 \mathrm{~m}$ deep waters of the Norwegian Channel. The site will likely be developed as Norway's first large-scale floating offshore wind park, covering an area of $1010 \mathrm{~km}^{2}$. The Norwegian Government intends to divide the site into up to three development areas, with the selection process for developers set to begin at the end of 2021 (Norwegian Ministry of Petroleum and Energy, 2021).

The area in which Utsira Nord is located has a complex geological history of repeated ice stream activity and sediment transport linked to the waxing and waning of the Scandinavian Ice sheet (SIS) during the last 1.1 million years (Sejrup et al. 1994, 1995, 2003, 2005; Nygård et al. 2005; Hjelstuen et al. 2012, 2018; Reinardy et al. 2017). Ice stream activity has also had an impact on marine ground conditions in other previously glaciated regions with good wind resources, such as the coastlines of Canada, the northern United States and the northern United Kingdom (Fig. 2). Understanding the geological and geotechnical heterogeneities of the seabed and shallow subsurface in previously glaciated areas therefore has important implications for designing safe and cost-effective offshore wind foundations and anchors in these regions. 
The goal of this paper is to present a preliminary conceptual geological model for the Utsira Nord site which combines an overview of previous knowledge about the complex ice streaming history of the Norwegian Channel with key observations from high resolution bathymetric data, 2D seismic data and sub-bottom profiles covering the site, and shallow cores from the surrounding area. We demonstrate a method which can advance conventional "desktop studies" towards a more cross-disciplinary and powerful tool for understanding the key risks and uncertainties in the ground conditions at new offshore wind sites. Despite limited data coverage, this method allows four main geotechnical provinces at the Utsira Nord site to be defined: 1) exposed glacimarine to marine sediments ("soft" marine clays, silts, sands and gravels) suitable for suction-type anchors, 2) buried to exposed subglacial traction till ("soft" glacial clays, silts, sands and gravels) suitable for suction-type anchors, 3) buried lodgment till (glacial clays, silts, sands and gravels and boulders) of uncertain geotechnical character and 4) shallowly buried to exposed crystalline bedrock which would require a pile-based or novel anchoring solution were it to be developed. The model is intended as a starting point for the development of a "ground truth" model of the site and summarizes the geotechnical properties and design challenges anticipated at the site. This can serve as a basis for planning geotechnical and geophysical site survey activities at the Utsira Nord site, and as a useful reference for offshore wind sites on other formerly glaciated coasts where palaeo ice stream systems are common.

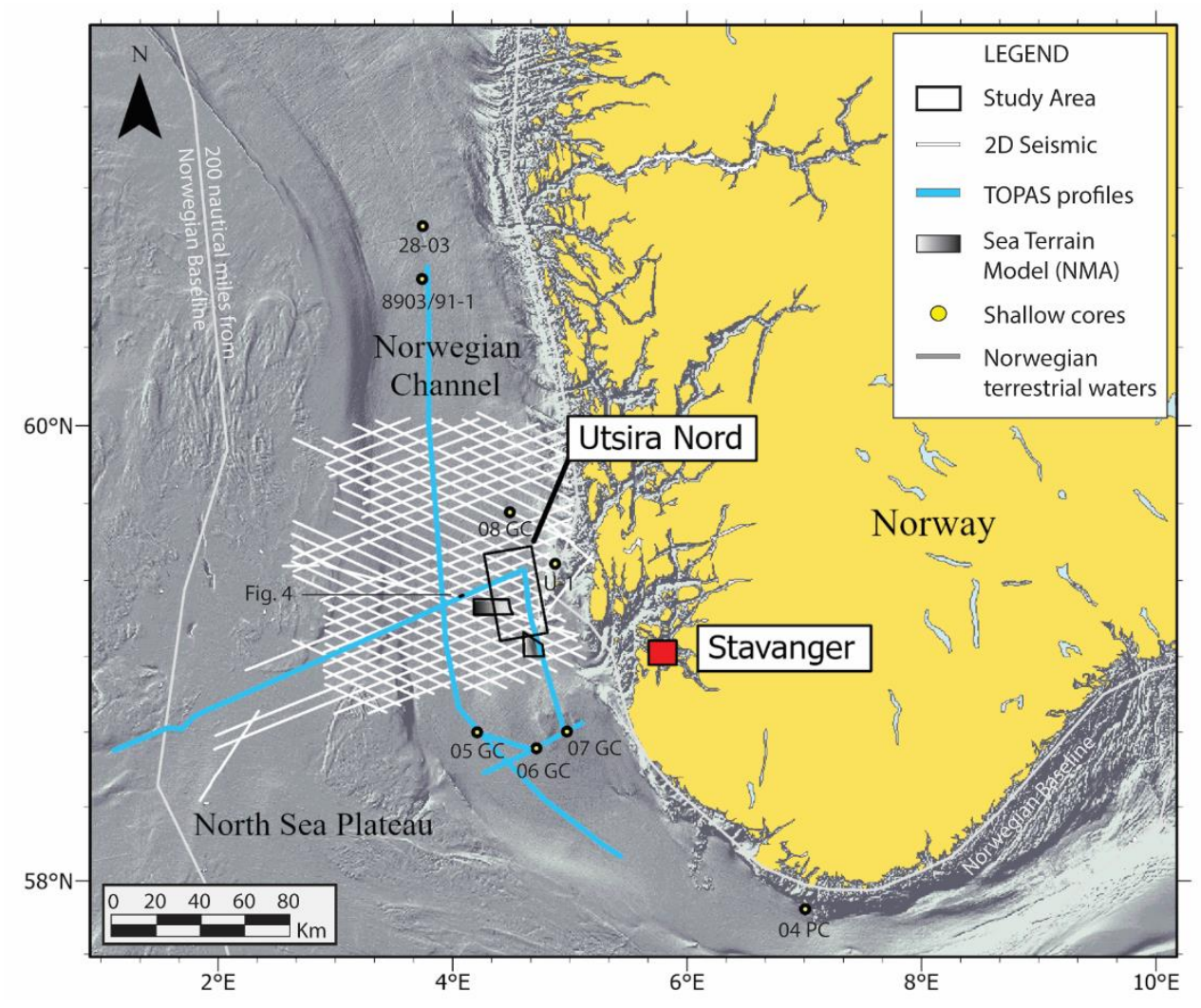

Fig. 1. Bathymetric hill-shaded map of the Norwegian North Sea (www.olex.no) showing the location of the Utsira Nord site, and the dataset used in this study. Two small parts of the site are covered by the Norwegian Mapping Authority (NMA) $5 \mathrm{~m}$ resolution Sea Terrain Model (2018). TOPAS acoustic profiles, gravity/piston cores (05-GC08-GC, 04-PC) were acquired on a University of Bergen cruise in 2012 (Hjelstuen et al. 2018; Morén et al. 2018). The 2D seismic surveys (ST8201 R90 \& R92) are sourced from the DISKOS repository. Piston core 28-03 and drilled core 8903/91-1 are reference cores for the sedimentary infill of the Norwegian Channel (Klitgaard-Kristensen et al. 1998; Sejrup et al. 1994, 1995). Drilled core 27/9-U-1 penetrates Jurassic sedimentary bedrock east of Utsira Nord (Rokoengen and Sørensen, 1990). 


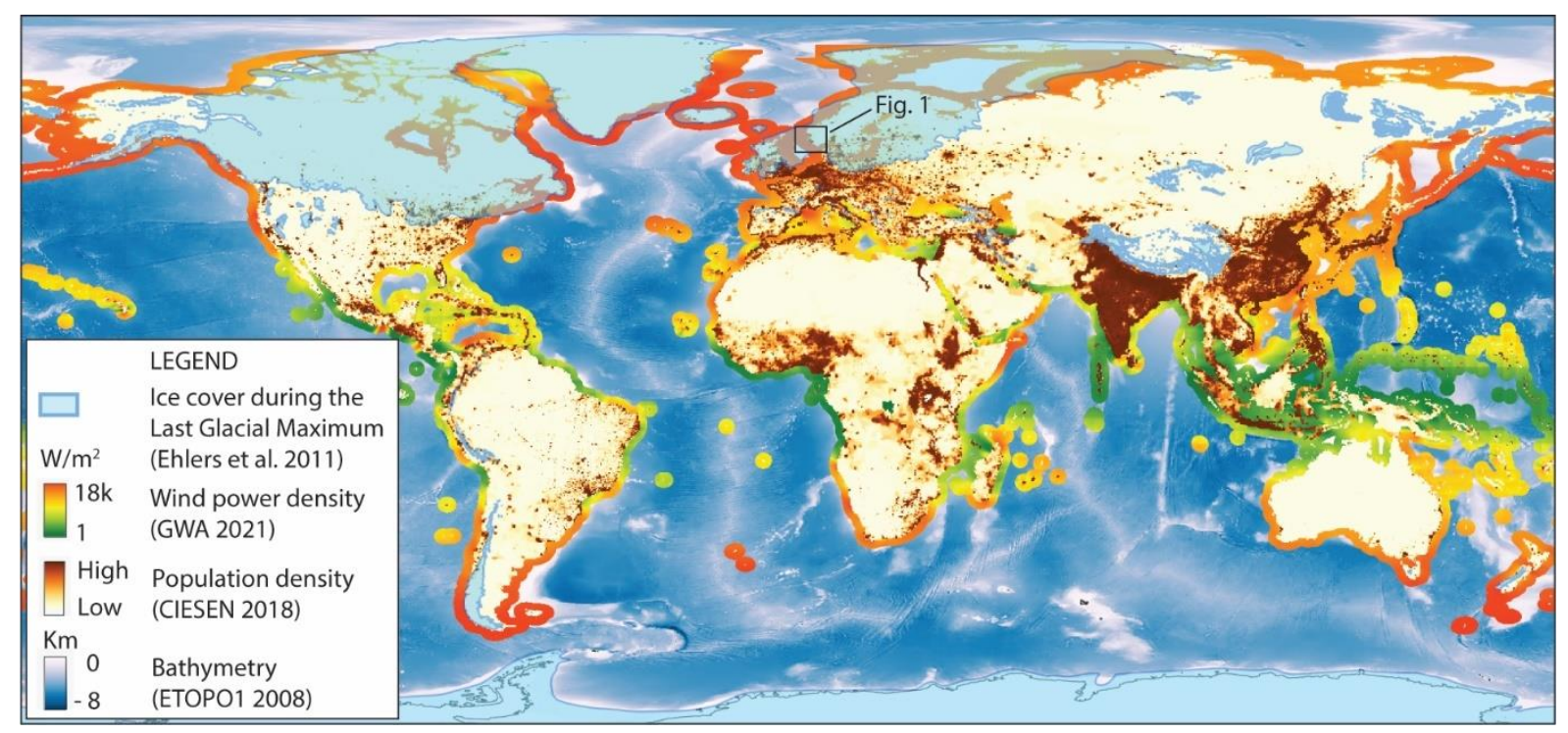

Fig. 2. Global map of ice extent (glaciated areas) during the Last Glacial Maximum ( 20 ka) (Ehlers et al. 2011), wind power density at $100 \mathrm{~m}$ (Global Wind Atlas, 2021) and world population density (CIESIN, 2018) giving an overview of the coastlines where ice streaming has been an important geological process and where good wind resources and large population centers are present. Background bathymetry is from ETOPO1 Global Relief Model (NOAA, 2008).

\section{Geological Background}

\section{The North Sea}

The North Sea is an epicontinental shelf of 50-400 m water depth, located between the United Kingdom and Northern Europe. During the Cenozoic, the North Sea formed a wide depocenter in which up to ca. $3 \mathrm{~km}$ of sediments were deposited (Gatliff et al., 1994). These sediments were sourced from erosion of the landmasses on both sides of the North Sea, which were uplifted during two main phases (Faleide et al., 2002): 1) late Paleocene to early Eocene uplift related to the break-up of the northeast Atlantic and the Iceland plume and 2) the Plio-Pleistocene isostatic response to glacial erosion during the Northern Hemisphere glaciations.

During the Quaternary period $(<2.6 \mathrm{Ma}$ ), the Northern European landmasses experienced repeated glaciations (e.g., Dahlgren and Vorren, 2003; Ehlers et al. 1984; Ehlers and Gibbard, 2004; Sejrup et al. 2005; Lee et al. 2012). It was during the Fedje glaciation 1.1 million years ago that the SIS is thought to have extended beyond at least the southwest and mid-Norwegian coastline for the first time (Haflidason et al. 1991; Sejrup et al. 1994, 1995). Across large areas of the North Sea, regional seismic profiles show evidence of extensive glacial erosion in the form of flat-lying Pleistocene beds and incised channels which truncate Upper Pliocene clinoforms and the lower part of the Pleistocene sequence (Sejrup et al. 1991; Eidvin et al. 2000, Graham et al. 2011). In cored sediments sampled above the giant gas field Troll (sediment core 8903/91-1), a glacial deposit dated to $1.1 \mathrm{Ma}$, named the Fedje till, is directly superimposed on Oligocene strata (Sejrup et al. 1995).

After 1.0 Ma, the Quaternary climate cycles became more intense, resulting in more extensive glaciations and warmer interglacial periods (Ruddiman et al. 1986; Shackleton et al. 1990; Jansen et al. 1990, 2000). Glacial landforms mapped on bathymetric data and information from sediment cores indicate that the SIS, the British Isles Ice Sheet (BIIS) and the Barents Sea-Kara Ice Sheet eventually merged at 160-140 ka and again during the Late Glacial Maximum at $20 \mathrm{ka}$, encompassing a large 
marine area from Svalbard to Ireland (Ehlers and Gibbard, 2004; Svendsen et al. 2004; Sejrup et al. 2005; Lee et al. 2012; Hughes et al. 2016). Along the coast of south and southwestern Norway, an approximately $200 \mathrm{~km}$ wide zone of fast-flowing ice known as the Norwegian Channel Ice Stream (NCIS) formed within the merged SIS-BIIS ice sheets (Ottesen et al. 2016). Glacial debris flows at the mouth of the Norwegian Channel located (at the North Sea shelf edge) indicate that the NCIS was active at least five times between 0.5 Ma and 18 ka (King et al. 1996; Sejrup et al. 2003; Rise et al. 2004; Nygård et al. 2005). These repeated ice streaming events eroded the underlying bedrock to form the $850 \mathrm{~km}$ long, 200-700 m deep Norwegian Channel in which the Utsira Nord site is located (Fig. 1).

The initial deglaciation and break-up of the NCIS started between 19-18.7 ka at the North Sea shelf edge, reaching the inner part of Skagerrak by 17.6 ka (Morén et al. 2018). After this, warm coastal currents began to occupy the Norwegian Channel (Sejrup et al. 1994; Haflidason et al. 1995, 1998), with some periodic ice input from the fjords during minor readvances of the SIS (Mangerud et al. 2011). Sea level rose rapidly, and fine-grained marine sediments were deposited at relatively high rates (220 $\mathrm{g} / \mathrm{cm}^{2} / \mathrm{ka}$ between 15-13 ka, Haflidason et al. 1998), with occasional coarser input from calved ice. Until $\sim 10 \mathrm{ka}$, the climate remained relatively unstable. Ice retreat was occurring rapidly in the fjords and on the Scandinavian landmass, resulting in continuing high sedimentation rates in the fjords and the Norwegian Channel (Nesje et al. 1991; Nesje and Dahl, 1993). After 9 ka, the deglaciation was largely over and marine sedimentation rates in the channel became much lower $\left(4 \mathrm{~g} / \mathrm{cm}^{2} / \mathrm{ka}\right.$, Haflidason et al. 1998). The thickest Holocene sediments (up to $50 \mathrm{~m}$ thickness, Morén et al. (2018)) are found along the western margin of the channel, fed from the North Sea Plateau and along the eastern margin of the channel offshore western Norway, fed from the western fjords.

\section{Seismic- and Litho-stratigraphy of the Norwegian Channel}

The base of the Norwegian Channel is defined by a regional erosion surface known as the Upper Regional Unconformity (URU), (e.g., Sejrup et al. 2000; Ottesen et al. 2014), which truncates westward dipping Mesozoic and Cenozoic sedimentary rock (Fig. 3). The overlying Quaternary sediments deposited by the NCIS are generally flat-lying and extensive, often with erosive bases that truncate the older channel sediments (Sejrup et al. 1995). The term glacial till is used to describe sediments which have been transported and then deposited by a glacier, ice sheet or ice stream (Dreimanis and Lundquist, 1984). These sediments tend to contain a mixture of clay, silt and coarser rock fragments ranging from sand and gravel to boulder size. Units of till which are associated with a particular morphological deposit, for example from the sides or front of the glacier, are described as moraines (e.g., lateral moraine, terminal/end moraine). Off western Norway, the Norwegian Channel fill consists of repeated glacigenic sequences comprising till (10-50 m thick) overlain by finer-grained glacimarine and marine sediments (Sejrup et al. 1996). Commonly, the sequences are not completely preserved but can comprise several generations of till, glacimarine or marine sediments separated by glacial erosion surfaces (Sejrup et al., 1996). The number of preserved sequences decreases southwards towards the Skagerrak Strait, where only the youngest sequence is preserved (Haugwitz and Wong, 1993). The key geotechnical parameters of the Norwegian Channel tills, glacimarine and marine sedimentary units from the Troll reference core are defined in Figure 4 and will be further explored within the Results and Discussion sections of this paper.

In previous studies, the upper $\sim 50 \mathrm{~m}$ of the Norwegian Channel sedimentary infill has been subdivided into two to three main acoustic units, based on high-resolution sub-bottom profiler (TOPAS) data correlated to shallow sediment cores (Fig. 4) (Sejrup et al. 1994; Nygård et al. 2007; Morén et al. 2018). 


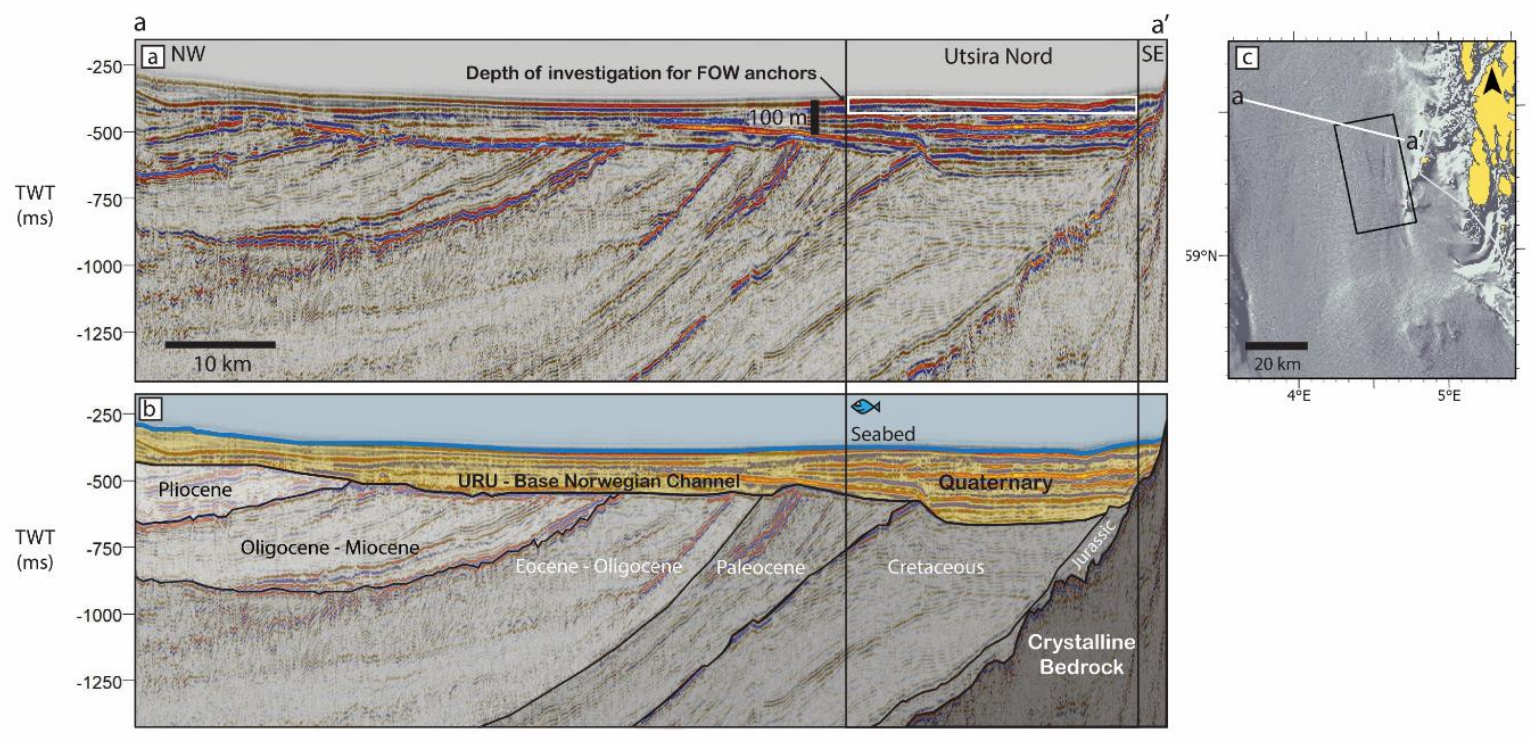

Fig. 3. (a) Uninterpreted regional 2D seismic section (a-a') across the Norwegian Channel from survey ST8201 R92 showing two-way travel time in milliseconds (ms) and depth ( $m$ ) for the Norwegian Channel late Quaternary infill and standard depth of investigation for FOW anchor site surveys, (b) Interpreted 2D seismic section (a-a') from ST8201 R92 showing outcropping crystalline bedrock along the eastern boundary of the Norwegian Channel, sub-cropping Mesozoic to Cenozoic sedimentary bedrock along the base of the Norwegian Channel and the Late Quaternary infill of the channel, (c) Location map for profile a-a' on Olex bathymetry.

The lowermost unit, interpreted as glacial till, is acoustically homogeneous except for an internal reflector mapped 5-40 m below the top of the unit (R1 in Fig. 4). This internal reflector is mostly found in the outer parts of the Norwegian Channel. Sejrup et al. (1994) and Morén et al. (2018) group the till above and below this reflector is into one unit (Unit B1 and Unit U1 respectively), while Nygård et al. (2007) divide the till into two units (U3 and U2) (Fig. 4). Based on studies of palaeo ice stream systems in Antarctica (O' Cofaigh et al. 2007, King et al. 2009, Reinardy et al. 2011), Morén et al. (2018) propose that the internal reflector which defines the upper and lower parts of the till represents a boundary between a softer upper till (traction till), affected by the most recent ice stream deformation and a lower, over consolidated till (lodgment till) which progressively became buried deeply enough to avoid further deformation. The strong reflector which defines the top of the till ( $R 2$ in Fig. 4) is generally highly irregular due to glacial erosion and deformation. Where it has been exposed at the seabed during the last deglaciation, $\mathrm{R} 2$ is less distinct and highly perturbated by iceberg plough marks. The base of the till is not generally observed on sub-bottom profiler data due to limited penetration depth, however the shallowest till unit within the Troll core off western Norway (Sejrup et al. 1995) has a thickness of $57 \mathrm{~m}$. Further south in the Skagerrak Strait, this till has been found to be thinner, around $30 \mathrm{~m}$ thick, and deposited directly on Mesozoic bedrock rather than older till layers (Bøe et al. 1998). Except for the Troll core which penetrates ca. $220 \mathrm{~m}$ through several sequences of tills, very few cores have penetrated the upper till unit in the Norwegian Channel. Those which do have only sampled the upper few metres of the till. Based on the limited core data available (05-GC-08-GC, 04-PC, Fig. 1), the upper part of the till appears to consist mainly of dark grey, fine-grained sediments, with occasional sand and silt lenses and laminae, and gravel to cobble-sized clasts. It also exhibits deformational structures, such as shear planes and zones (Morén et al. 2018). At the Troll field, the youngest till unit is a very homogeneous clay to silty clay which contains close to $30 \%$ sand and $2-3 \%$ coarse sand and gravel (Sejrup et al. 1995). Drilling and core recovery issues encountered during the collection of the 
core (Sejrup et al. 1995) also indicate the presence of boulders or coarse, consolidated material within the tills encountered above the Troll field.
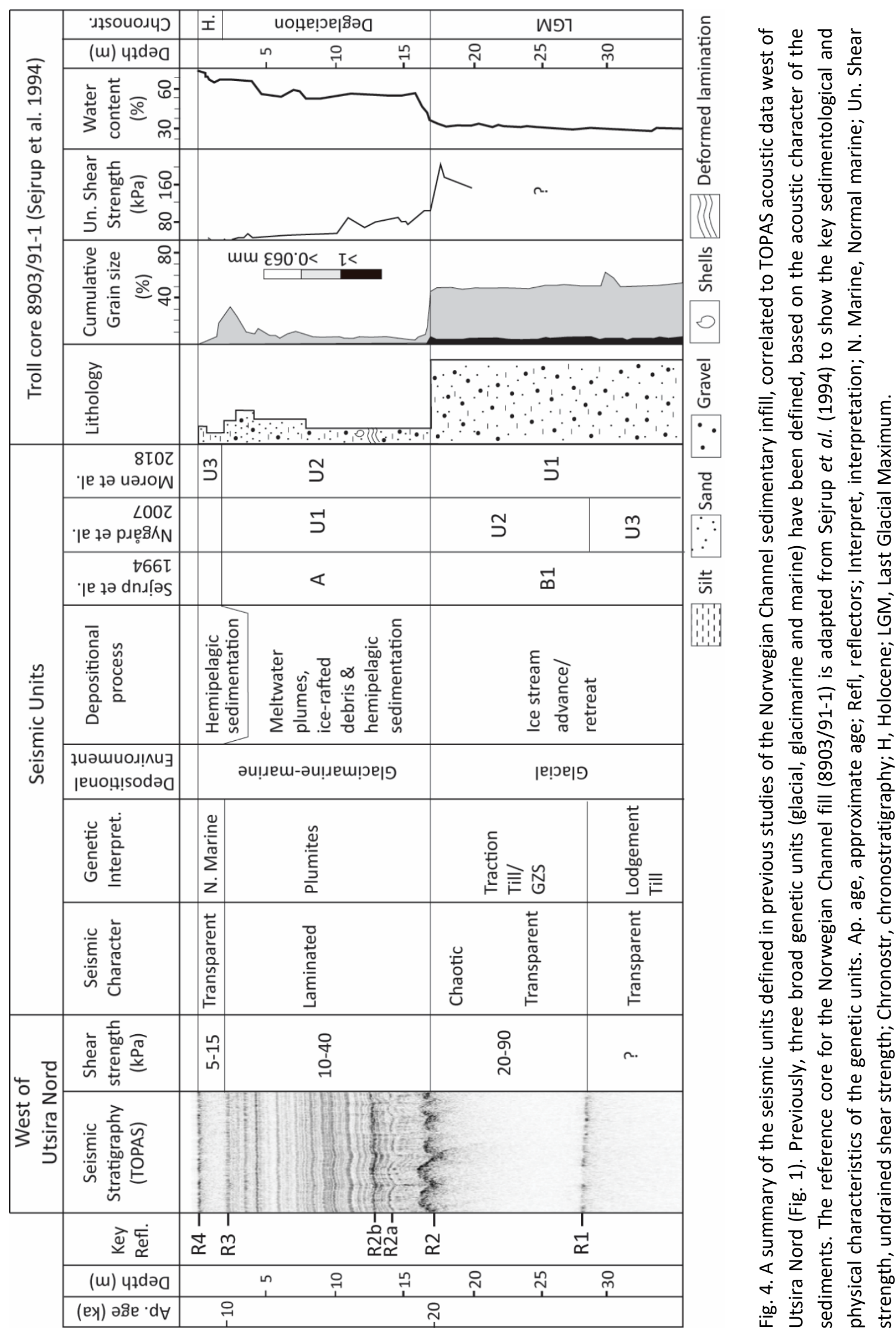
Topographic lows on the till surface, such as glacially eroded troughs, are commonly infilled by an acoustically laminated unit, which is in turn overlain by an acoustically transparent unit (defined respectively as U2 and U3 by Morén et al. (2018)). In other studies, these units are grouped together as one (Unit A in Sejrup et al. (1994) and Unit U1 in Nygård et al. (2007), Fig. 4). The laminated unit, interpreted as glacimarine sediments deposited rapidly by sediment-laden meltwater plumes during the last deglaciation, reaches maximum thicknesses of up to $100 \mathrm{~m}$, but is generally 5-20 m thick off western Norway and 15-40 m thick off southern Norway (Morén et al. 2018). The transition from the underlying till into the laminated glacimarine sediments is correlated in sediment cores to a decrease in sand and coarse material and a marked decrease in undrained shear strength (Sejrup et al. 1994; Morén et al. 2018). The top of the laminated unit (R3, Fig. 4) is defined by a more regular and lower amplitude reflector than R2. The overlying acoustically transparent unit, interpreted as post-glacial marine sediment, drapes conformably over the laminated sediments, and is generally around 5-10 m thick off western Norway and 5-20 m thick in southern Norway, but can reach thicknesses up to $50 \mathrm{~m}$. While both the glacimarine and marine units generally consist of fine-grained sediments with occasional shell fragments, there is generally a change in grain size distribution from the glacimarine to marine unit. The nature of this change varies in different parts of the Norwegian Channel, with the marine sediments observed to be coarser than the glacimarine sediments off western Norway, while off southern Norway, the marine sediments are observed to be finer than the glacimarine sediments (Morén et al. 2018).

\section{Method}

This study combines an overview of previous knowledge about the sedimentary infill of the Norwegian Channel with key observations from bathymetric data, 2D seismic data, sub-bottom profiles, and shallow cores. Geological interpretations from the data were integrated to define a conceptual geological model for the Utsira Nord site which is divided into provinces with contrasting prognosed geotechnical properties and implications for FOW anchor design. While the standard depth of subsurface investigation for seabed anchors today is $30 \mathrm{~m}$, the model investigates the upper $50 \mathrm{~m}$ of the subsurface stratigraphy. This is to contribute towards a more complete understanding of the geological context of the site and to facilitate site investigations for possible pile-based anchoring designs which may require a larger depth of investigation. The estimated distribution and thickness of the four provinces across the site were then used to generate risk maps which highlight areas with challenging conditions for floating offshore wind anchors.

\section{Data}

Large-scale geomorphological features related to ice stream erosion and deposition were interpreted on a bathymetric map of the North Sea from the Olex AS single beam echosounder database (Fig. 5). The resolution of the map varies spatially depending on the density of seafloor measurements from fishing and other vessels in a particular area. The data are gridded to $5 \mathrm{~m} \times 5 \mathrm{~m}$, however not every cell contains a data point. Finer features such as pockmarks, boulders and iceberg plough marks are therefore not generally distinguishable on the Olex map but were interpreted on the $5 \times 5 \mathrm{~m}$ Sea Terrain Model from the Norwegian Mapping Authority (2018), which covers two small swathes of the Utsira Nord site (Figs. 5d, 5e).

2D seismic data within the Utsira Nord site and greater Norwegian Channel region (Fig. 1) was sourced from DISKOS (The Norwegian National Data Repository for Petroleum Data) and includes the surveys: 
ST8201 (reprocessed surveys R90 and R92), NPD-KYST-96, NSR-04 and NSR-05. The quality of the data is good enough to interpret the broad structural and sedimentary features of the Norwegian Channel, despite the presence of strong multiples of the seabed reflector and base Norwegian Channel reflector (in ST8201 R90, Fig. 6). The seabed reflector and the base of glacial erosion within the Norwegian Channel (the "Upper Regional Unconformity (URU)" reflector) were interpreted and then depth converted using seismic velocities of $1500 \mathrm{~m} / \mathrm{s}$ (average P-wave velocity for seawater) and $1800 \mathrm{~m} / \mathrm{s}$ (based on the P-wave velocity of the Quaternary (Nordland Group) sediments encountered in exploration well 35/2-1 (Bellwald et al. 2020) respectively. The resulting depth surfaces were used to generate a thickness map of the channel fill and to investigate the regional structure of the channel in the vicinity of the Utsira Nord site. Two parametric sub-bottom (TOPAS) profiles acquired in 2012 by the University of Bergen (details of the cruise are referenced in Hjelstuen et al., 2018) cross the northern and eastern parts of the site (Fig. 1). The TOPAS profiles have a vertical resolution of 25-30 $\mathrm{cm}$, approximately ten times finer than that of the 2D seismic data. The profiles were therefore used to interpret key reflectors, acoustic facies, and seabed features not visible on the 2D seismic profiles.

Four gravity cores and a piston core, all located more than $15 \mathrm{~km}$ distance from the Utsira Nord site, were acquired in 2012 by the University of Bergen (the piston core is presented in Morén et al. (2018)) (Fig. 1). Sedimentological analysis of the cores were integrated with seismic observations from the TOPAS seismic profiles to interpret the depositional environment of each seismic facies identified. The core analysis presented in this study includes a short summary of the bulk densities, undrained shear strengths and grain size distributions for cores 05-GC, 06-GC and 07-GC which were considered most relevant for the facies present within Utsira Nord. Shallow core 27/9-U-1, north of Utsira, (Fig. 1) acquired between $96-176 \mathrm{~m}$ below seabed as part of the SINTEF IKU shallow drilling project, was used to investigate the underlying Mesozoic sediments at the base of the Norwegian channel within the site. These sediments were dated by Rokoengen and Sørensen (1990) to an Upper Jurassic age. The overlying Quaternary sediments, however, were not cored or preserved as cuttings in that campaign. Core-logging as part of this study found that the sedimentary bedrock north of Utsira consists of unconsolidated to consolidated, fine-grained, shallow marine sand containing wood and shell fragments. However, as the formation occurs at depths greater than the depth of investigation for offshore wind anchors and foundations, the logs are not presented in this paper.

Results

\section{Bathymetric Data}

The Utsira Nord site is characterized by a trough (T1) along its eastern side, where water depths exceed $280 \mathrm{~m}$, and a shallower, flatter area (Grounding Zone System (GZS) 1) along its western side where water depths exceed $250 \mathrm{~m}$ (Figs. 5a, 5b, 5c). A Grounding Zone System is a backstepping wedge of subglacial and pro-glacial sediments deposited during the episodic retreat of an ice stream (e.g., Rüther et al. 2011). Several GZS's are interpreted in this part of the Norwegian Channel based on their elongated, mound-like bathymetry with curved, steeply dipping northerly termini (GZS 1-4, Figs. 5a, $5 c$ ). The shallower bathymetry along the western side of the Utsira Nord site (GZS 1) and a small part of the site in the southeast (GZS 3) are therefore also interpreted as Grounding Zone Systems.

A chain of rugged bathymetric highs (annotated as exposed bedrock in Figs. 5a, 5b) is observed in the southeastern corner of the site and to the east of the site, the largest of which is the island of Utsira (Fig. 5a). Within the Utsira Nord site there are three main bathymetric highs, which increase in height southwards from $30 \mathrm{~m}$ to $85 \mathrm{~m}$ above the seabed. Based on the bedrock geology of the western 
Norwegian coastline and the island of Utsira, the highs in Utsira Nord are interpreted as exposed crystalline (metamorphic) bedrock, characteristic of the Norwegian West Coast.
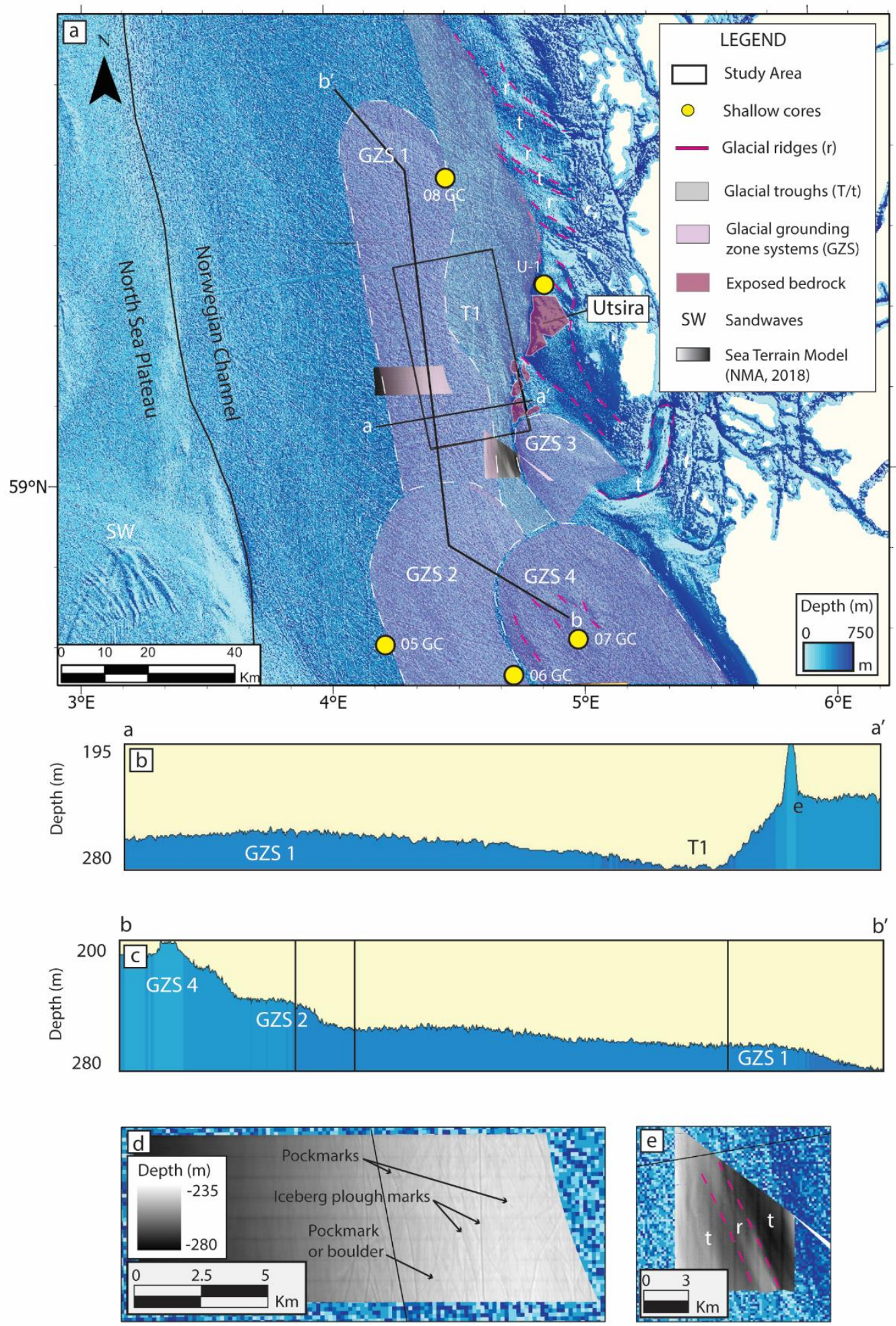

Fig. 5. (a) Olex bathymetric map of the Utsira Nord site and surrounding area showing interpreted geomorphological features (glacial troughs [t] and ridges [r], glacial grounding zone systems [GZS], and sandwaves [sw]), (b) East-west bathymetric cross-section through GZS 1, trough [T1] and an exposed bedrock high [e] in the southeastern corner of Utsira Nord, (c) North-south bathymetric cross-section through GZS 1, 2 and 4, (d) Annotated NMA Sea Terrain Model (2018) showing iceberg plough marks, pockmarks and a possible boulder or pockmark in western Utsira Nord, (e) Glacial troughs and ridges south of Utsira Nord. 
East and northeast of the site, the seabed is characterized by many curved troughs ( $t$ ) and ridges ( $r$ ), which are oblique to the Norwegian Channel. Such features are common along the west coast of Norway and were interpreted by Rise and Rokoengen (1984) as moraines formed between confluent ice flows from the western Norwegian coast and the main NCIS. Ottesen et al. (2016) suggest that the sediments from the last glaciation were remolded into ridges by ice entering the channel from the western Norwegian coast, with stronger erosion occurring between the ridges to form the troughs. Both interpretations point towards a strong glacial influence on the bathymetry of the Utsira area and to the presence of glacial till at or near the seabed.

On the high-resolution Sea Terrain Model (Figs. 5a, 5d, 5e), finer-scale seafloor features are identified in the western and southeastern parts of the site. In the shallower western part of the site (GZS 1), northward striking straight to curvilinear features several metres deep, tens of metres wide and several kilometers long are abundant (Fig. 5d). These are typical iceberg plough marks, scours in the seafloor sediments created by northward-floating icebergs released during the last deglaciation (e.g., Lien, 1983). In contrast, the deeper trough area (T1) in southern Utsira Nord, largely lacks iceberg plough marks, and instead is characterized by north-northwestward striking glacial trough $(t)$ and ridge $(r)$ features of several kilometers' width (Fig. 5e).

In the western part of the site, several raised circular features with a central depression which are over $200 \mathrm{~m}$ in diameter and several metres deep are observed (Fig. 5d). These are interpreted as pockmarks, crater-like features from which water or gas is escaping or has previously escaped and which could indicate the location of small-offset faults within the subsurface. Such features are common on the seafloor within the Norwegian Channel (e.g. Forsberg et al., 2007). In addition to pockmarks, the Sea Terrain Model also reveals two smaller (over $50 \mathrm{~m}$ in diameter and several metres high) raised circular features in the western part of the site (Fig. $5 \mathrm{~d}$ ). While these likely represent smaller pockmarks, they might represent boulders lodged within glacial till or deposits of ice-rafted debris.

\section{D Seismic Data}

2D seismic profiles give an overview of the structure and geometry of the Norwegian Channel in the Utsira Nord area (Fig. 6). The base of the channel slopes gently eastwards, defined by a reflector of variable character which truncates westward-dipping sedimentary bedrock of Late Jurassic through to Pliocene age. The total thickness of the channel infill on the eastern side of the channel, where Utsira Nord is located, is $\sim 300 \mathrm{~m}$, thinning to $\sim 100 \mathrm{~m}$ on the western side of the Norwegian Channel (Fig. 7b). Utsira Nord is located along the eastern side of the Norwegian Channel, where the NCIS has eroded into Jurassic, Cretaceous and Palaeocene sediments (Fig. 6b). The more resistant crystalline bedrock forms a steep-sided wall along the eastern side of the channel and is commonly exposed at the sea floor along the western Norwegian coastline (Figs. 6b, 6c, Fig. 7d). The crystalline bedrock has a chaotic seismic character, is highly segmented by steeply dipping faults and has a strong hard top reflector and rugged surface (Figs. 6a, 6b, 6c). In some parts of the site, particularly in the eastern and central areas, the crystalline bedrock faults continue upwards into the sedimentary bedrock and Quaternary sedimentary cover. The location of these faults may correlate with the location of pockmarks on the site; however, 3D seismic data would be required to confirm this.

The chain of crystalline bedrock highs identified on the Olex bathymetry map (Fig. 5a) are intersected in several places by the 2D conventional seismic dataset. As the 2D seismic profiles are spaced $\sim 6 \mathrm{~km}$ apart, the seabed depth map (Fig. 7a) and Norwegian Channel thickness map (Fig. 7b) interpreted on 
the seismic data resolve only two out of the three main bedrock highs identified on the Olex bathymetry in the southeastern corner of Utsira Nord. The thickness of the Norwegian Channel sedimentary infill within 1-3 km from the exposed rock areas, ranges from 0-30 m to 30-60 m (Fig. 7b). This is expressed as a "risk map" for anchoring conditions in Figure 7c, where areas of exposed bedrock are marked in red, areas with sedimentary cover thinner than $30 \mathrm{~m}$ are marked in yellow and areas with sedimentary cover thinner than $60 \mathrm{~m}$ are marked in white. Areas where additional rocky outcrops are known to exist from bathymetric data are also marked in red, with dashed contours indicating the estimated sedimentary thickness around the exposures.

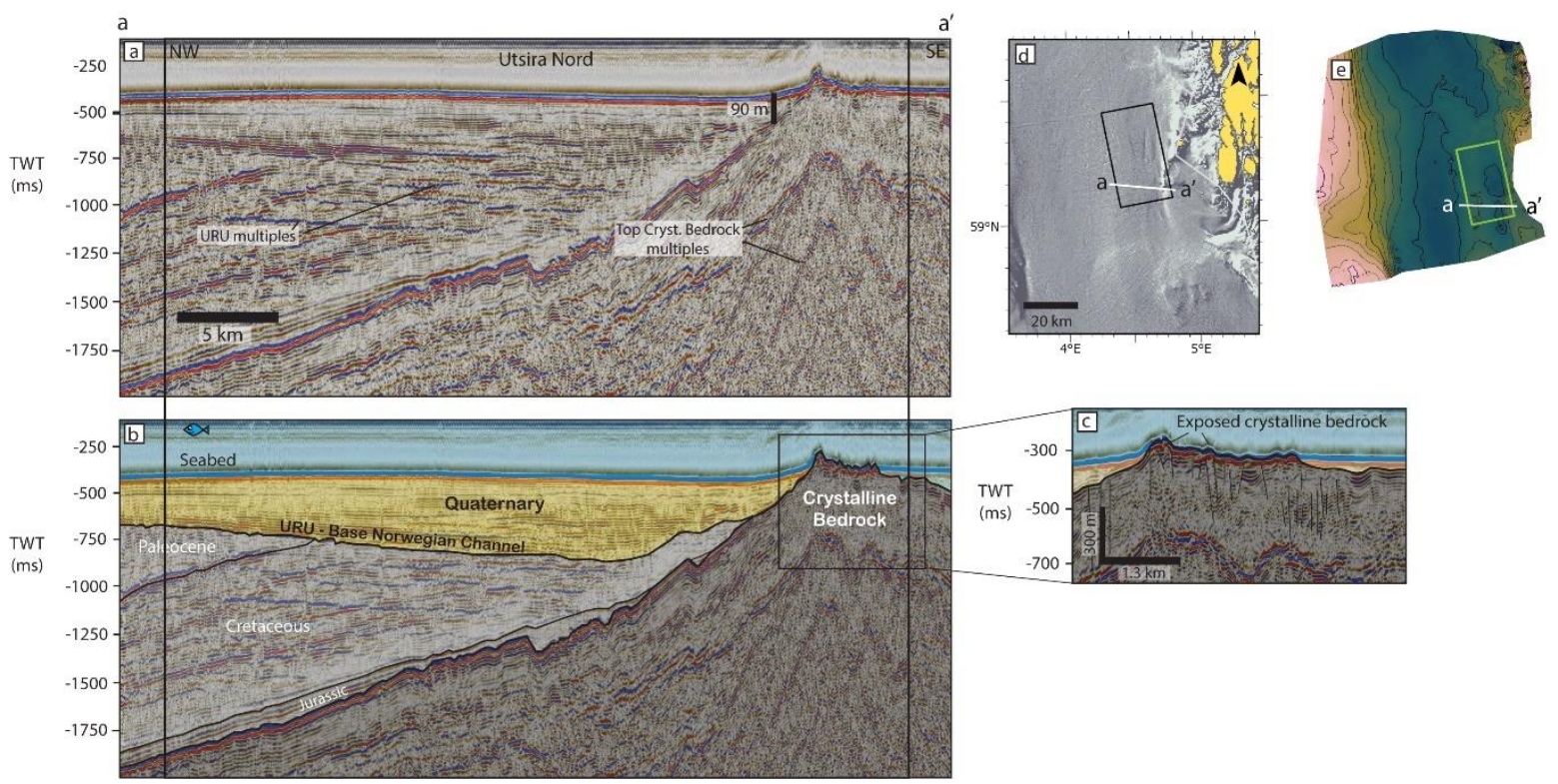

Fig. 6. (a) Uninterpreted 2D seismic section across southern Utsira Nord from survey ST8201 R90, (b) Interpreted 2D seismic section from ST8201 R90 showing outcropping and shallowly buried crystalline bedrock in the southeastern part of Utsira Nord, (c) A more detailed view of the exposed bedrock with interpreted faults, (d) Location map for profile a-a' on Olex bathymetry (e) Location map for profile a-a' on the 2D seismic seabed depth surface.

\section{Sub-bottom Profiles}

The TOPAS sub-bottom profiles within Utsira Nord reveal seabed features and acoustic facies within the upper 30-50 m of the subsurface which are not resolvable on the bathymetric and 2D seismic datasets (Fig. 8a vs Fig. 8b). Within the northern part of the site (Fig. 8a), seismic reflectors are only visible down to $25 \mathrm{~m}$ below seabed. The dominant seismic facies present is a chaotic seismic unit containing abundant high amplitude point diffractors which becomes increasingly transparent with depth. Based on previous studies of the Norwegian Channel seismic stratigraphy (e.g., Nygard et al. 2007; Morén et al. 2018) this unit is interpreted as subglacial traction till which consists of mixed glacial clay, sand, gravel, and cobbles deformed by the NCIS. The point diffractors are tentatively interpreted as possible boulders or lenses of coarse, consolidated sediment within the generally fine-grained, muddy-sandy matrix of the till. In the northeastern part of the profile, a faint, relatively flat reflector occurs 10-20 m below the top of the subglacial till. This type of internal till reflector has been identified in many parts of the Norwegian Channel on high resolution seismic profiles (Morén et al. 2018) and in Antarctic palaeo ice streams (O' Cofaigh et al. 2007; King et al. 2009) and is interpreted to represent the boundary between a soft upper layer of subglacial traction till and a more compacted deeper layer of lodgment till. 


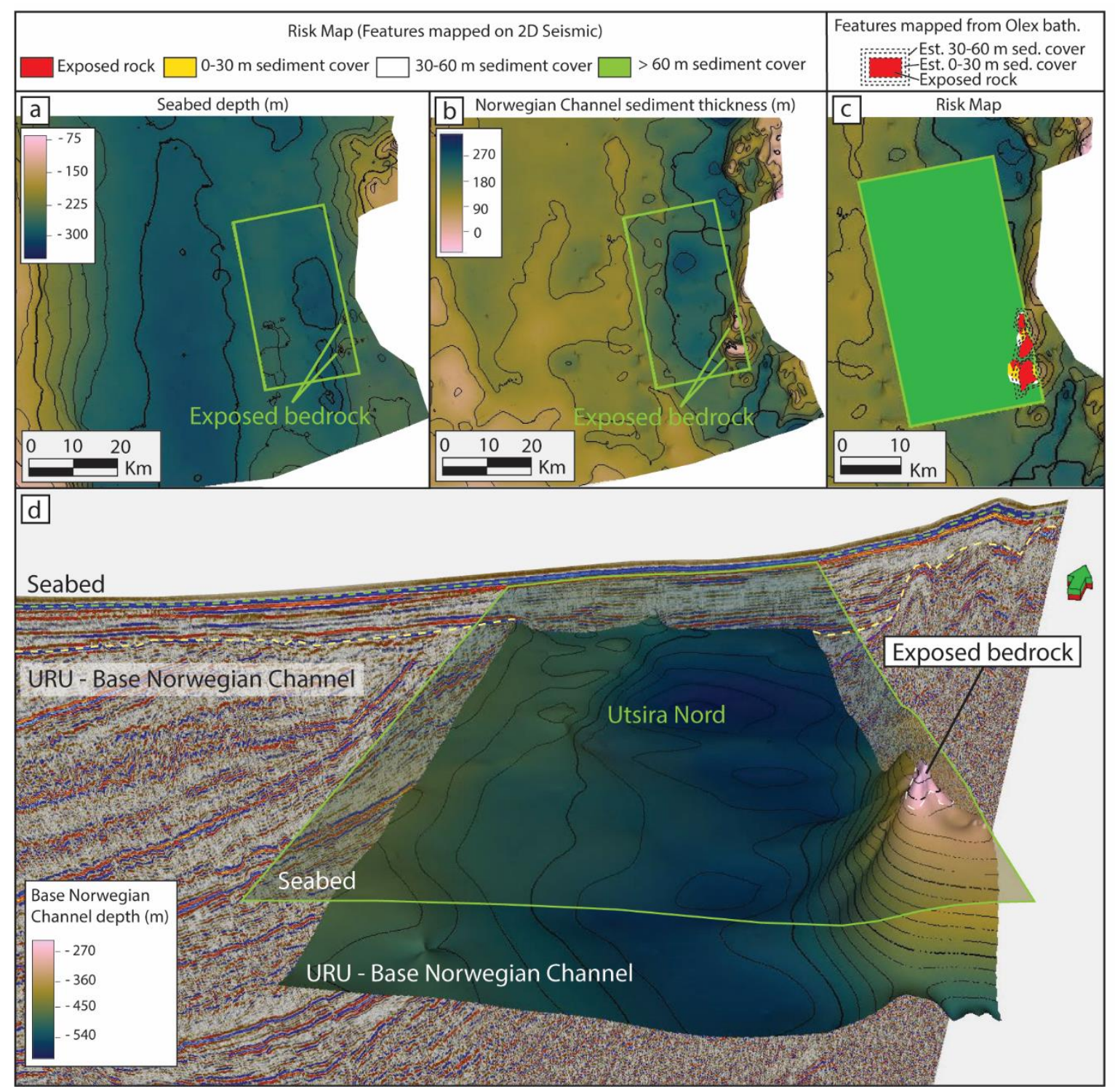

Fig. 7. (a) Seabed depth map interpreted on 2D seismic survey ST8201 (R90 \& R92), showing the location of Utsira Nord in green. Bedrock highs observed in the southeastern part of the site are interpreted as exposed crystalline bedrock, (b) Seabed - Base Norwegian Channel sediment thickness map, showing where Quaternary sediments are thin to absent in southeastern Utsira Nord, (c) Risk map for anchoring conditions, based on (b) and bathymetric data where seismic data are absent (bath, Bathymetry; Est. sed. cover, estimated sedimentary cover, (d) Seabed depth map and Base Norwegian Channel depth map (Upper Regional Unconformity-URU) within the Utsira Nord site showing a semi-regional 2D seismic profile across the northern part of the site from survey ST8201 R90 exhibiting the seismic character of buried crystalline bedrock to the east of the site and sub-cropping sedimentary rock at the base of the channel to the west of the site. The extent of crystalline bedrock exposed at the seabed as far as can be determined from 2D seismic is shown with white stippled line. 

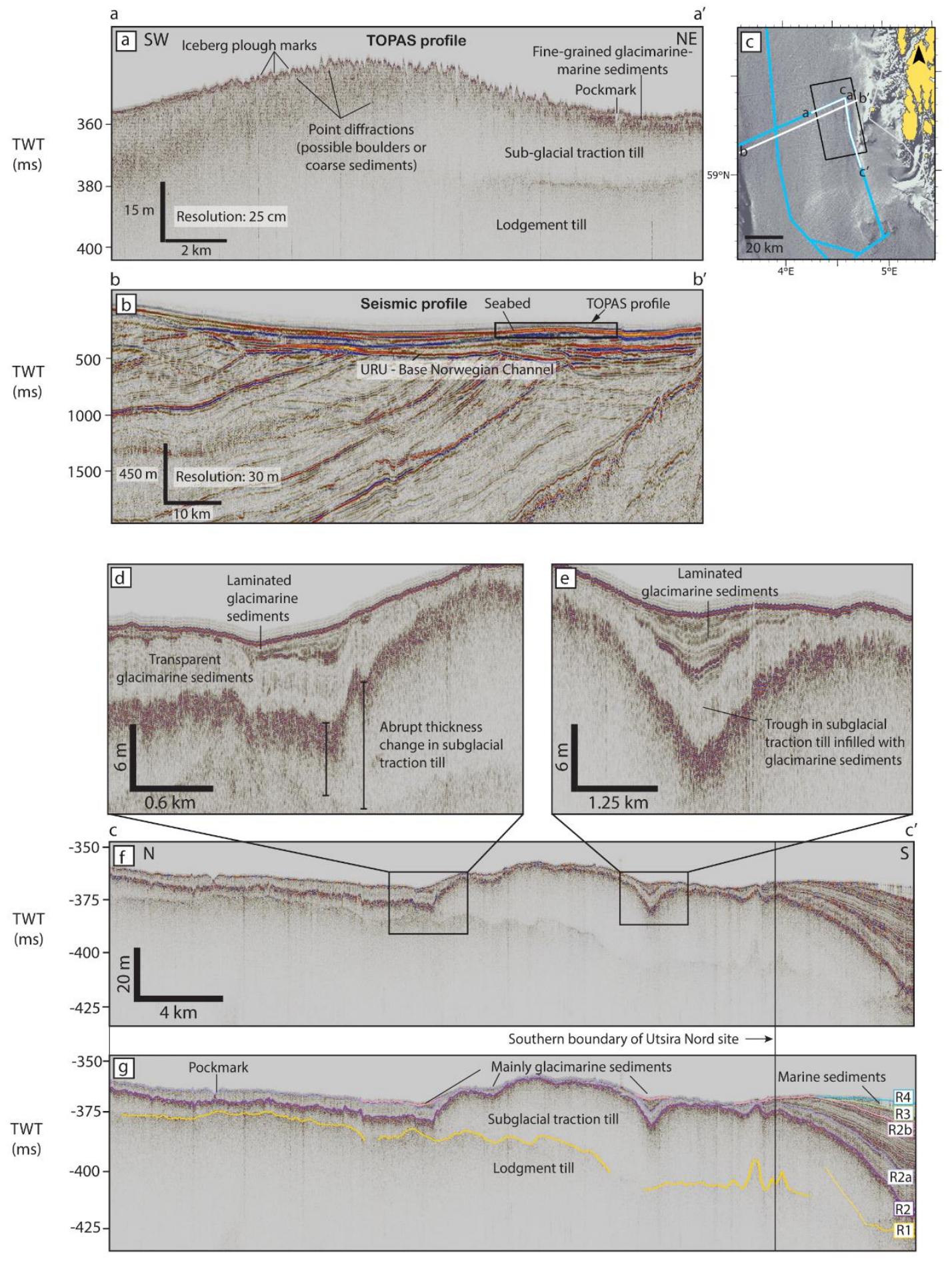

Fig. 8. (a) Uninterpreted TOPAS profile a-a' across northern Utsira Nord showing key features distinguishable on high-resolution acoustic data compared with conventional 2D seismic profile b-b', (b) conventional 2D seismic profile b-b' from survey ST8201 R92. Location and depth of penetration of (a) is shown in the context of existing 2D seismic data available at the site, (c) Location map for profiles a-a', b-b' and c-c' on Olex bathymetry, (d) Zoomed-in section from profile c-c' showing glacimarine sediment infilling a trough in sub-glacial traction till, (e) Additional zoomed-in section of an infilled trough from profile $\mathrm{c}^{-\mathrm{c}^{\prime}}, \mathrm{g}$ ( Interpreted version of TOPAS profile c-c' showing key reflectors R1-R4 and the interpreted genetic units defined between. 
In the central part of the profile, the subglacial traction till has a mounded geometry and is exposed at the seabed. The seabed here is highly furrowed, a characteristic feature of iceberg plough marks from the deglaciation period (e.g., Lien, 1983). In the northeastern and southwestern parts of the profile, the till is onlapped by a thin $(<3 \mathrm{~m})$, transparent seismic unit which fills the iceberg plough marks in the underlying till unit. In the northeastern part of the profile, a $4 \mathrm{~m}$ deep pockmark cuts through both the glacimarine unit and the underlying till. This transparent unit is interpreted as fine-grained glacimarine sediment from the deglaciation period, based on the westward thickening of the unit west of the Utsira Nord site, where it exhibits laminations characteristic of glacimarine sedimentation (e.g., Sejrup et al. 1989, 1994). Thick post-glacial marine sediments observed west of the Utsira Nord site are not distinguishable over the western and eastern flanks of the Utsira Nord till, but a few centimeters to tens of centimeters of post-glacial muddy to sandy marine sediments (below the resolution of the TOPAS profile) could be present.

A north-south TOPAS profile in the eastern part of the site reveals variations in the thickness of the upper and lower till units and the overlying glacimarine unit within Utsira Nord (Figs. 8d, 8e, 8f, 8g). The flat internal reflector interpreted to define the base of the upper till becomes progressively deeper from north to south, meaning that the upper till layer is 5-15 $\mathrm{m}$ thick in the northern part of Utsira Nord increasing to 15-45 m thick in the southern part. Glacimarine sediments are present at the seabed across the whole profile, with a relatively constant thickness of 7-10 $\mathrm{m}$ in the northern half of Utsira Nord. In the southern half of Utsira Nord, the thickness of the glacimarine sediments is more variable, thinning to only a few meters over highs in the glacial till, and thickening to up to $12 \mathrm{~m}$ in troughs in the glacial till (Figs. 8d, 8e). In these troughs, the transparent glacimarine sediments observed across the rest of the profile are overlain by laminated glacimarine sediments. The same laminated facies are observed south of the Utsira Nord site, where the thickness of both the transparent and laminated glacimarine sediment packages increases rapidly to a total thickness of $45 \mathrm{~m}$. These are overlain by a transparent, southwards thickening package thought to represent post-glacial marine sediments which thin to less than $30 \mathrm{~cm}$ (below TOPAS resolution) thickness over the Utsira Nord site.

\section{Gravity Cores}

Key geotechnical properties of some of the acoustic facies identified within Utsira Nord can be estimated from the gravity cores $05-07-G C$, located approximately $50 \mathrm{~km}$ south of the site where the same acoustic facies are present at or near the seabed (Fig. 1). The range of undrained shear strengths measured within each of the acoustic facies are summarized in Figure 4, while a brief sedimentological description of the cores is provided here.

The subglacial traction till facies (Fig. 4) is penetrated by cores 06-GC and 07-GC. Both cores are located where the till is exposed at or near the seabed, within interpreted grounding zone systems (GZS 2 and GZS 4 respectively) (Fig. 5a). The facies consist of silty clay, with lenses of fine sand, shell fragments, plant fragments, whole shells, and gravel. The grainsize is uniform throughout, with a sand content between $45-60 \%$ and the density of the sediments ranges from $1.65-1.95 \mathrm{~g} / \mathrm{cm}^{3}$. The undrained shear strength of the till is rather variable, mainly ranging from $20-90 \mathrm{kPa}$. Observed deformation structures are indicative of deformation either by ice push during the glaciation or iceberg ploughing which took place during deglaciation.

The glacimarine facies (Fig. 4) is penetrated by cores 05-GC and 06-GC and consists of laminated clay to silty clay with lenses of fine sand, shell fragments and chalk clasts. The density of these sediments 
ranges from 1.4-2.4 g/ $\mathrm{cm}^{3}$, while the undrained shear strength is low, ranging between $5-25 \mathrm{kPa}$. In core $05-G C$, the glacimarine facies is overlain by normal marine facies (Fig. 4). This consists of clay with a density of $1.7-2.3 \mathrm{~g} / \mathrm{cm}^{3}$ and very low undrained shear strengths of between $5-15 \mathrm{kPa}$.

\section{Discussion}

\section{Conceptual Model for Utsira Nord and how it relates to anchoring of floating offshore wind}

Based on the distribution and properties of the seismic units identified at Utsira Nord, four main geotechnical provinces are defined (Fig. 9, Table 1).

The region of exposed to shallowly buried crystalline bedrock within the southeastern corner of the Utsira Nord site, which comprises about $10 \%$ of the site, is defined as Province 4 . The bedrock likely consists of very hard metamorphic rock such as gneiss, which has a shear strength greater than 3.5 MPa (Singh and Murthy, 2016). Suction anchors designed for soft clays and muds and driven piles designed for sandy soils will not be a feasible design concept for this part of the site due to the risk of obstruction, shallow refusal, variable penetration and buckling (Table 1, Table 2). Instead, a drilled pile or a novel anchoring system will likely be required to develop this part of the site (Table 2). Gravitybased anchors (Table 2) might also be a feasible solution, however the risk of sliding on the rugged, uneven slopes of exposed bedrock (with an average gradient of up to $8^{\circ}$ ) will need to be evaluated. This may require acquisition of higher resolution bathymetry data to more accurately assess the steepness of the bedrock slopes. If economically feasible, the geophysical site survey should focus on mapping the shallowly buried parts of the bedrock in more detail (Table 1), ideally using 3D seismic to better constrain the subsurface extent of the crystalline bedrock and the sediment thicknesses around the exposures. This will give a clearer overview of how close soft sediment anchors can be placed to the bedrock exposures.

The lodgment till layer interpreted beneath reflector 1 (Fig. 8g) is defined as Province 3. There is a large uncertainty around the sedimentary and physical properties of this province, due to a lack of cores which sample this type of sediment within the Norwegian Channel and other paleo ice stream systems. However, it is likely that the lower till layer is denser due to greater consolidation and less glacial deformation. It is suggested that Province 3 will exhibit undrained shear strengths at least as high or higher than those measured in the upper till at the Troll field (80-160 kPa, (Sejrup et al. 1995)). The undrained shear strength of lodgment tills from geotechnical borings onshore UK in the range of 50$640 \mathrm{kPa}$ have been reported by Clarke et al. (1998), although the values were mainly below $300 \mathrm{kPa}$. Heavily over-consolidated tills from Canada with undrained shear strengths of greater than $3000 \mathrm{kPa}$ (Milligan, 1976) and up to $1600 \mathrm{kPa}$ in North America (Radhakrishna and Klym, 1974) have also been reported, however such extreme consolidation is not anticipated within a paleo ice stream such as the Norwegian Channel due to higher pore water pressure (Tulaczyk and Kamb, 2000; Kamb, 2001; KyrkeSmith et al. 2013) and thinner ice cover than passive inter-ice stream areas (Gandy et al. 2021). If the Utsira Nord lodgment till is similar to the youngest till unit at the Troll field, a lithology of homogeneous clay to silty clay with around $30 \%$ sand and $3 \%$ coarse sand and gravel can be expected (Sejrup et al. 1995). Although the drilling issues experienced at Troll indicate the presence of boulders or coarse, consolidated sediments within the till units, the distribution of boulders throughout the Norwegian Channel remains highly uncertain. An abundance of boulders or course sediments could have a significant impact on the anchor design for the Utsira Nord site, for example a requirement for increased suction anchor wall thickness. Based on the north south TOPAS line (Fig. 8g), Province 3 is likely to mainly occur 45-50 m below the seabed in the southern half of the site and is therefore unlikely 

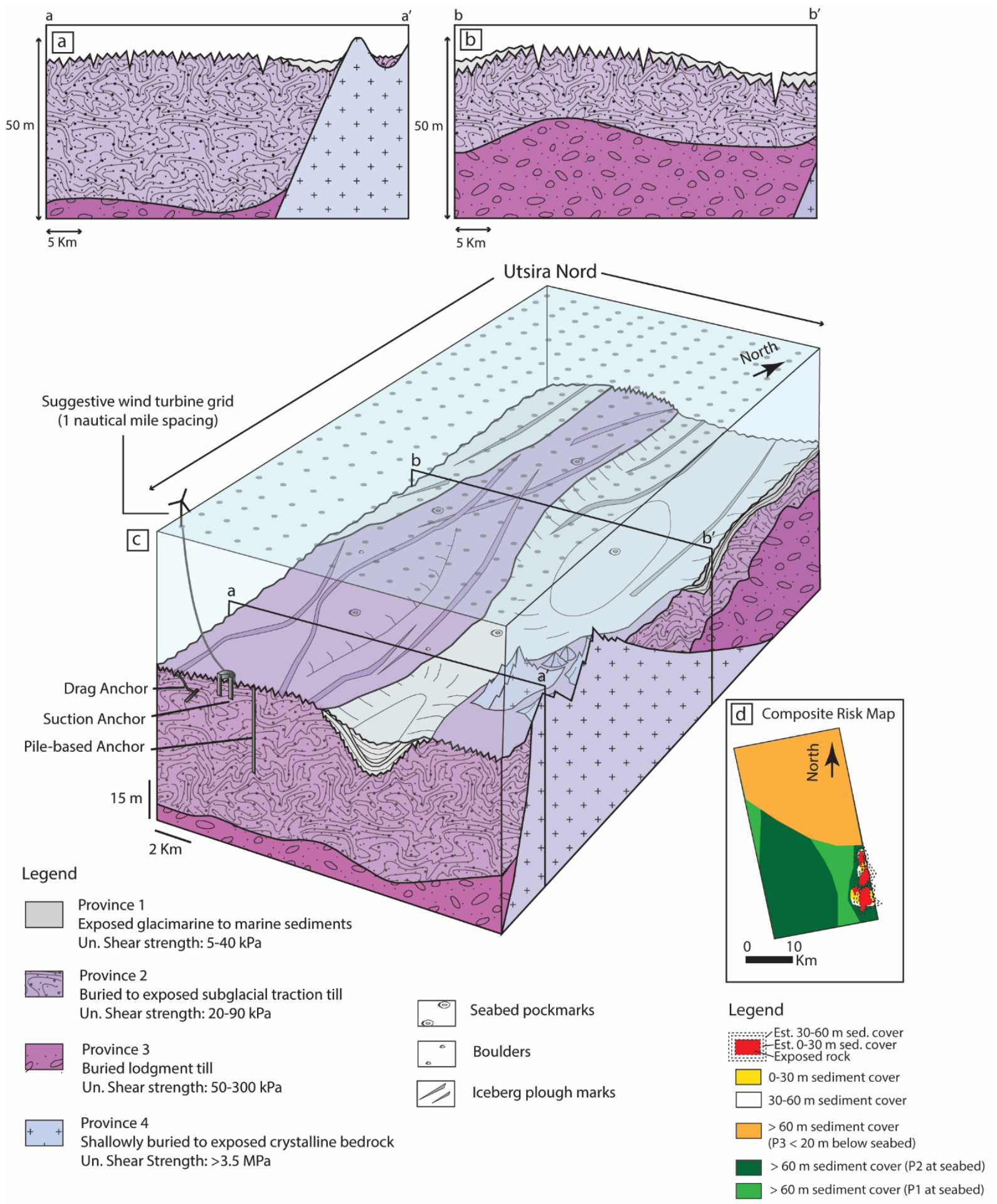

Fig. 9. (a) Geosection a-a' showing how the respective provinces of the conceptual geological model for Utsira Nord Conceptual vary in thickness and burial depth across the southern part of the site, (b) Geosection b-b' showing variations across the northern part of the site, (c) Geological model for Utsira Nord based on the bathymetric and acoustic data covering the site. The upper $50 \mathrm{~m}$ of the sub-sea stratigraphy and the seabed are divided into four geotechnical provinces. The overlying seawater is represented in transparent blue (not to scale), with a suggestive grid of floating offshore wind turbines spaced $1 \times 1$ nautical mile. Schematic drawings of three anchor types give an impression of how vertical and lateral changes in the seabed and the subsurface conditions can impact anchor design and penetration. Sources of undrained shear strength values are given in Table 1, (d) Composite risk map combining the bedrock versus sediment cover risk map from Fig. 7c with a visual representation of the estimated distribution and thickness of Provinces 1-3 across the Utsira Nord site. 
Table 1. Risk matrix summarizing the characteristics of the geotechnical provinces defined at Utsira Nord

\begin{tabular}{|c|c|c|c|c|c|}
\hline $\begin{array}{l}\text { Geological } \\
\text { Province }\end{array}$ & Description & Hazards & Causes & Potential Impact & Mitigation \\
\hline \multirow{3}{*}{1} & \multirow{3}{*}{$\begin{array}{l}\text { Exposed glacimarine to } \\
\text { marine sediments } \\
\text { Un. Shear strength: } 5-40 \mathrm{kPa} \\
\text { (Gravity and piston cores) }\end{array}$} & \multirow[t]{2}{*}{ Uneven seabed } & $\begin{array}{l}\text { Pockmarks } \\
\text { Iceberg Scours }\end{array}$ & Variable anchor penetration & \multirow[t]{2}{*}{$\begin{array}{l}\text { High resolution seabed mapping } \\
\text { (sonar, 3D seismic) }\end{array}$} \\
\hline & & & Boulders & Obstruction to anchor & \\
\hline & & $\begin{array}{l}\text { Poorly consolidated } \\
\text { sediment }\end{array}$ & $\begin{array}{l}\text { Recent marine } \\
\text { sediments deposited } \\
\text { by currents }\end{array}$ & $\begin{array}{l}\text { Seabed scour around } \\
\text { anchors }\end{array}$ & $\begin{array}{l}\text { In-situ testing across site to } \\
\text { determine degree of consolida- } \\
\text { tion of recent sediments }\end{array}$ \\
\hline 2 & $\begin{array}{l}\text { Buried to exposed subglacial } \\
\text { traction till } \\
\text { Un. Shear strength: } 20-90 \mathrm{kPa} \\
\text { (Gravity cores) }\end{array}$ & $\begin{array}{l}\text { Sudden lateral variation } \\
\text { in soil properties }\end{array}$ & $\begin{array}{l}\text { Glacial troughs with } \\
\text { softer sediment infill }\end{array}$ & Variable anchor penetration & $\begin{array}{l}\text { Acquisition of } 2 \mathrm{D} \text { or } 3 \mathrm{D} \text { acoustic } \\
\text { data to map filled glacial troughs } \\
\text { on finer scale }\end{array}$ \\
\hline \multirow{2}{*}{3} & \multirow{2}{*}{$\begin{array}{l}\text { Buried lodgment till } \\
\text { Un. Shear strength: } 50-300 \mathrm{kPa} \\
\text { (Clarke et al., 1998) }\end{array}$} & $\begin{array}{l}\text { Buried hard formation } \\
\text { at varying depths }\end{array}$ & $\begin{array}{l}\text { Overconsolidation of } \\
\text { sediment by repeated } \\
\text { ice activity }\end{array}$ & $\begin{array}{l}\text { Obstruction to anchor } \\
\text { Variable anchor/pile } \\
\text { penetration }\end{array}$ & \multirow{2}{*}{$\begin{array}{l}\text { Acquisition of } 2 \mathrm{D} \text { or } 3 \mathrm{D} \text { acoustic } \\
\text { data to map Top Province } 3 \text { on } \\
\text { finer scale } \\
\text { Acquisition of core and in-situ } \\
\text { testing across site to determine } \\
\text { variability in soil properties }\end{array}$} \\
\hline & & $\begin{array}{l}\text { Highly variable soil } \\
\text { properties }\end{array}$ & $\begin{array}{l}\text { Poorly sorted mixture } \\
\text { of clay, silt, sand, } \\
\text { gravel, cobbles, } \\
\text { boulders }\end{array}$ & $\begin{array}{l}\text { *Potential impact increases } \\
\text { northward as province } \\
\text { closer to surface }\end{array}$ & \\
\hline \multirow{2}{*}{4} & \multirow{2}{*}{$\begin{array}{l}\text { Shallowly buried to exposed } \\
\text { crystalline bedrock } \\
\text { Un. Shear Strength: }>3.5 \mathrm{MPa} \\
\text { (Singh and Murthy, 2016) }\end{array}$} & Uneven seabed & \multirow{2}{*}{$\begin{array}{l}\text { Rugged bedrock } \\
\text { topography with } \\
\text { exposed and buried } \\
\text { peaks }\end{array}$} & \multirow{2}{*}{$\begin{array}{l}\text { Obstruction to anchor } \\
\text { Shallow refusal } \\
\text { Variable pile penetration } \\
\text { Pile buckling }\end{array}$} & \multirow{2}{*}{$\begin{array}{l}\text { High resolution seabed mapping } \\
\text { (sonar, 3D seismic) and sub-bot- } \\
\text { tom profiling in south eastern } \\
\text { part of the site }\end{array}$} \\
\hline & & Buried hard formation & & & \\
\hline
\end{tabular}

to have implications for anchor design considerations in this area. In the northern part of the site however, Province 3 appears likely to mainly occur 10-20 m below the seabed and must therefore be considered within the anchor design concept. Province 3 may present a risk to successful penetration of suction anchors designed for clays and muds; however, borehole investigations will be required in the northern part of the site to analyze the physical properties of the Province 3 sediments further (Table 1).

The subglacial traction till layer interpreted between Reflector 1 and Reflector 2 (Fig. 8g) is defined as Province 2. The sedimentary and physical properties of Province 2 can be estimated from the shallow cores in the vicinity of the site which comprise silty clay with sand lenses, gravel, deformation structures and undrained shear strengths of up to $90 \mathrm{kPa}$. This province is likely to be suitable for suction type anchors where it extends to at least 30-40 m beneath seabed. This is most likely in the southern part of the site as discussed above. Province 2 is likely to be exposed at or within tens of centimeters of the seabed along the shallower central and western parts of the site. Sudden lateral variations in soil properties can be expected where glacial troughs filled with softer, younger sediments are present at the surface of Province 2 (Table 1). This could result in variable anchor penetration of soft sediment anchors (suction anchors, drag anchors, Table 2) along the boundaries of the troughs, so their extent should be mapped in greater detail as part of the geophysical site survey (Table 1).

The glacimarine sediments which overlie the subglacial traction till layer are defined as Province 1. Post-glacial marine sediments are not visible on the TOPAS profiles which cover Utsira Nord, however a thin $(<25-30 \mathrm{~cm}$ ) layer of fine-grained marine sediments across the whole site cannot be ruled out. The glacimarine sediments vary in thickness and distribution across the Utsira Nord site, thickening in the bathymetric lows on the surface of Province 2 to up to $12 \mathrm{~m}$ thickness, and thinning over the highs. The sedimentary and physical properties of Province 1 can be estimated from the shallow offset cores in the vicinity of the site which comprise clay to sandy silt with sand lenses, gravel, shell fragments and undrained shear strengths of $20 \mathrm{kPa}$ (and up to $40 \mathrm{kPa}$ in piston core $04 \mathrm{PC}$ in southern Norwegian Channel (Morén et al. 2018)). This province is likely to be suitable for suction type anchors, with due 
consideration given to the properties of the underlying till. The key hazards associated with Province 1 (and Province 2 where it is exposed at the seabed) are the presence of pockmarks, iceberg plough marks and possible boulders/coarse material dropped from icebergs during the deglaciation period. The unevenness of the seabed and the possibility of encountering boulders should be given due consideration during the anchor installation phase but can be mitigated through high-resolution seabed mapping (Table 1). The Province 1 sediments are likely to be very soft, clay-rich sediments but could also contain poorly consolidated coarser-grained sediments vulnerable to scouring around emplaced anchors. In-situ testing of the Province 1 and Province 2 sediments exposed at the seabed should be conducted across different parts of the site to evaluate the risk of seabed scour (Table 1).

Table 2. A summary of anchor types and soil conditions

\begin{tabular}{|c|c|c|c|c|}
\hline Anchor type & Description & Soil suitability & Advantages & Disadvantages \\
\hline $\begin{array}{l}\text { Suction anchor } \\
\text { (or suction caisson) } \\
\text { (or suction pile) }\end{array}$ & $\begin{array}{l}\text { Hollow steel cylinder with a } \\
\text { closed top, connected to a } \\
\text { pump which creates suction } \\
\text { (Vryhof anchors, 2010). }\end{array}$ & $\begin{array}{l}\text { Cohesive soils such as soft } \\
\text { clays. } \\
\text { Can be used in stiffer soils } \\
\text { if design adjusted e.g. } \\
\text { thicker walls. } \\
\text { Not suitable for bedrock. }\end{array}$ & $\begin{array}{l}\text { Suitable for a range of } \\
\text { mooring types. }\end{array}$ & $\begin{array}{l}\text { If porous sand layers } \\
\text { present, can have } \\
\text { problems with achieving } \\
\text { suction due to flow of } \\
\text { groundwater. }\end{array}$ \\
\hline Drag anchor & $\begin{array}{l}\text { Installed partly or fully } \\
\text { beneath the seabed by } \\
\text { dragging the anchor } \\
\text { through the soil (ABS, 2018). }\end{array}$ & $\begin{array}{l}\text { Range of cohesive soil } \\
\text { types including sand or } \\
\text { stiff clay, layered soils and } \\
\text { soft clay (ABS, 2018). } \\
\text { Not suitable for bedrock. }\end{array}$ & Cheap to produce. & $\begin{array}{l}\text { Final resting position has } \\
\text { degree of uncertainty. } \\
\text { Can make planning } \\
\text { difficult for dense turbine } \\
\text { grids. } \\
\text { Cannot currently be used } \\
\text { for shared moorings to } \\
\text { reduce number of } \\
\text { anchors required. }\end{array}$ \\
\hline Driven pile anchor & $\begin{array}{l}\text { Hollow steel pipe driven into } \\
\text { the seabed with a hammer } \\
\text { or vibrator (Ikhennicheu et } \\
\text { al., 2020). }\end{array}$ & $\begin{array}{l}\text { Range of cohesive soil } \\
\text { types including sand and } \\
\text { layered soils. Not suitable } \\
\text { for stiff soils or bedrock. }\end{array}$ & $\begin{array}{l}\text { Mature technology widely } \\
\text { used for foundation-based } \\
\text { offshore wind. }\end{array}$ & $\begin{array}{l}\text { Not suitable in water } \\
\text { depths greater than } 50 \mathrm{~m} \text {. }\end{array}$ \\
\hline Drilled pile anchor & $\begin{array}{l}\text { Hollow steel pipe installed } \\
\text { by drilling a borehole and } \\
\text { cementing the pile or filling } \\
\text { the borehole with sediment } \\
\text { (Lohning et al., 2021). }\end{array}$ & Stiff soil or bedrock. & $\begin{array}{l}\text { Allows flat areas with } \\
\text { shallow bedrock to be } \\
\text { developed. }\end{array}$ & $\begin{array}{l}\text { Expensive, } \\
\text { time-consuming to } \\
\text { install. }\end{array}$ \\
\hline Gravity anchor & $\begin{array}{l}\text { Block of concrete } \\
\text { or metal that sits } \\
\text { on the seafloor. }\end{array}$ & $\begin{array}{l}\text { Wide range of soil and } \\
\text { bedrock conditions. Not } \\
\text { suitable for very soft soil. } \\
\text { Not suitable for slopes. }\end{array}$ & $\begin{array}{l}\text { Easy to produce and } \\
\text { applicable to a wide } \\
\text { range of seabed } \\
\text { conditions. Useful if } \\
\text { conditions are uncertain. }\end{array}$ & $\begin{array}{l}\text { Large size and weight } \\
\text { leads to high installation } \\
\text { costs (James and Costa } \\
\text { Ros, 2015). }\end{array}$ \\
\hline
\end{tabular}

\section{Key Uncertainties}

With only several sparse and shallow gravity cores in the vicinity of the Utsira Nord site, several key uncertainties remain regarding the sedimentological and geotechnical character of Provinces 1-3. Although the glacimarine and marine sediments of Province 1 are generally well represented in previous studies (e.g., Sejrup et al. 1994; Morén et al. 2018), core locations tend to be tens to hundreds of kilometers apart, making it difficult to prognose what sort of site-scale variations might be present within Province 1. It should therefore be a topic of investigation to better constrain the lateral and vertical variability in the sedimentary and geotechnical properties of this province when acquiring site 
survey data at Utsira Nord. Although Province 1 is likely to comprise soft, fine-grained sediments, undrained shear strength and grainsize measurements from the site are required to confirm this. Troughs infilled by strongly laminated glacimarine sediments such as those observed along the eastern part of the site are particularly likely to be vertically heterogeneous and may contain sand layers that need to be investigated to inform suction anchor installation risk.

One of the key uncertainties remaining about Province 2 is what sets up the abundant point diffractors observed on sub-bottom profiles. It should be a goal of coring on the site to try to investigate if boulders or coarse ice-rafted debris deposits might be the cause of diffraction, as widespread distribution of such material on Utsira Nord could present significant installation risks to some anchor types. Existing gravity cores in the vicinity of the site have only sampled the upper tens of centimeters of the subglacial traction till facies. Deeper coring of Province 2 is therefore required to better understand the vertical and lateral variations in the sedimentary and geotechnical properties of subglacial traction till across the site.

The sedimentological and geotechnical properties of Province 3 are very uncertain as very little is documented about the sedimentary properties and internal variations within the Norwegian Channel lodgment till, other than studies related to the Troll core, located in the outer part of the Norwegian Channel. Shallowly buried lodgment till may present a risk to successful penetration of suction anchors designed for clays and muds, therefore site investigations should particularly focus on Province 3 in the northern part of the site where it is situated only 10-20 m below seabed. Province 3 might be too stiff and/or boulder-rich to be cored by piston corer and may require a drilled coring investigation.

While the undrained shear strength of the Province 4 crystalline bedrock is likely to be $>3.5 \mathrm{MPa}$, it is recommended that the fracture density and degree of weathering of the rock are investigated as part of geotechnical site survey investigations to determine the suitability of the rock for drilled pile emplacement if the province is to be developed. Given the location within the Norwegian Channel, the exposed rocks will most likely be ice-polished, with only highly resistant rock left behind. However, a high density of fractures or other structural weaknesses could affect the competence of the rock to hold an anchor. An additional aspect to be considered within Province 4 is that rocky marine areas are often characterized by high biodiversity relative to the surrounding soft bottom areas as their surface provides different microhabitats for marine organisms (Wenner et al. 1983; de Kluijver 1991; Diesing et al. 2009). This should be investigated further as part of the site's eventual environmental impact assessment.

\section{Conclusions and further work}

In this study, we demonstrate a method which can advance conventional "desktop studies" towards a more cross-disciplinary and powerful tool for understanding the key risks and uncertainties in the ground conditions at new offshore wind sites despite limited data availability. The conceptual geological model presented defines four main geotechnical provinces at the Utsira Nord floating offshore wind site: 1) exposed glacimarine to marine sediments suitable for suction-type anchors, 2) buried to exposed subglacial traction till suitable for suction-type anchors, 3) buried lodgment till with highly uncertain properties and likely boulders and 4) shallowly buried to exposed crystalline bedrock which will likely require a pile-based or novel anchoring solution of which approximately $10 \%$ of the site is estimated to comprise. In order to inform effective anchoring design and reduce installation problems, we recommend that initial geophysical and geotechnical site surveys at Utsira Nord focus 
on reducing the following key uncertainties: 1) the sedimentological and geotechnical character of Provinces 1-3 including the site-scale variability within each of the provinces, the sand content of the laminated trough-infill sediments in Province 1 and what geological conditions lead to the abundant point diffractors on sub-bottom profiles within Province 2 and 2) the sedimentological and geotechnical properties of Province 3 , which are particularly uncertain due to an almost complete lack of core sampling of lodgment tills within the Norwegian Channel. The key provinces and their associated data acquisition requirements identified at Utsira Nord are of relevance to current and future offshore wind developments in other formerly glaciated marine areas such as the coastlines of Canada, the northern United States, the northern United Kingdom and the rest of the Norwegian coastline, particularly within palaeo ice stream channels in these regions.

Offshore wind developers in Norway should use the lessons learned from previous offshore wind projects relating to insufficient understanding of geological setting and poor collaboration between site survey planners and foundation designers to avoid the need for unplanned additional data acquisition, installation problems and overconservative design solutions. As the Norwegian authorities develop the new offshore renewable energy licensing legislation, the importance of acquiring seabed, subsurface and environmental data as early as possible in the licensing and project development process should not be underestimated, regardless of who will pay the bill. Early data acquisition can facilitate both cost-effective and efficient foundation and anchoring design and installation and could contribute towards faster decarbonization of the European power sector. The openness of future data also needs to be clarified. Publicly available site survey data, such as are available from the Netherlands and the USA, could improve our understanding of the geological and environmental conditions at future offshore wind sites. Making offshore wind site survey data from the Norwegian North Sea publicly available could greatly benefit future Norwegian offshore wind projects and those within other previously glaciated areas.

\section{Acknowledgments}

This study is part of a PhD project at the University of Bergen funded and carried out in collaboration with Equinor Energy AS. We would like to thank the geologists, geophysicists and geotechnical engineers within the Equinor who have contributed to useful discussions about geological concepts for the Utsira Nord site, and their implications for floating offshore wind anchor design. Thanks to Olex AS, Trondheim for giving us permission to use their bathymetric data in several of the figures in this paper. Schlumberger are acknowledged for an academic license of Petrel which was used for seismic interpretation and visualization.

\section{References}

\section{Journal Articles}

Bøe, R., Rise, L. and Ottesen, D., 1998. Elongate depressions on the southern slope of the Norwegian Trench (Skagerrak): morphology and evolution. Marine Geology, 146 (1-4), pp.191-203. https://doi.org/10.1016/S00253227(97)00133-3

Clarke, B.G., Chen, C.C. and Aflaki, E., 1998. Intrinsic compression and swelling properties of a glacial till. Quarterly Journal of Engineering Geology, 31, pp. 235-246. https://doi.org/10.1144/GSL.QJEG.1998.031.P3.06

Dahlgren, K.I.T. and Vorren, T.O., 2003. Sedimentary environment and glacial history during the last 40 ka of the Vøring continental margin, mid-Norway. Marine Geology, 193 (1-2), pp. 93-127. https://doi.org/10.1016/S00253227(02)00617-5 
Deising, M., Coggan, R. and Vanstaen, K., 2009. Widespread rocky reef occurrence in the central English Channel and the implications for predictive habitat mapping. Estuarine, Coastal and Shelf Science, 83 (4), pp. 647-658. https://doi.org/10.1016/j.ecss.2009.05.018

Dreimanis, A., and Lundquist, J. 1984. What should be called till? Striae, 20, pp. 5-10. http://pascalfrancis.inist.fr/vibad/index.php?action=getRecordDetail\&idt=9679649

Ehlers, J. and Gibbard, P.L, 2004. “Quaternary glaciations-extent and chronology, part 1: Europe”. In: J. Rose (ed.) Developments in Quaternary Science, 2(1), pp. 1-475.

Ehlers, J., Meyer, K. and Stephan, H., 1984. The pre-weichselian glaciations of North-West Europe. Quaternary Science Reviews, 3 (1), pp. 1-9. https://doi.org/10.1016/0277-3791(84)90003-9

Eidvin, T., Jansen, E., Rundberg, Y., Brekke, H. and Grogan, P., 2000. The upper Cainozoic of the Norwegian continental shelf correlated with the deep sea record of the Norwegian Sea and the North Atlantic. Marine and Petroleum Geology, 17 (5), pp. 579-600. https://doi.org/10.1016/S0264-8172(00)00008-8

Faleide, J.I., Kyrkjebø, R., Kjennerud, T., Gabrielsen, R.H., Jordt, H., Fanavoll, S. and Bjerke, M.D., 2002. Tectonic impact on sedimentary processes during Cenozoic evolution of the northern North Sea and surrounding areas.

Geological Society, London, Special Publications, 196 (1), pp. 235-269.

https://doi.org/10.1144/GSL.SP.2002.196.01.14

Gandy, N., Gregoire, L.J., Ely, J.C., Cornford, S.L., Clark, C.D. and Hodgson, D.M., 2021. Collapse of the last Eurasian Ice Sheet in the North Sea modulated by combined processes of ice flow, surface melt, and marine ice sheet instabilities. Journal of Geophysical Research: Earth Surface, 126, e2020JF005755. https://doi.org/10.1029/2020JF005755

Gatliff, R.W., Richards, P.C., Smith, K., Graham, C.C., McCormack, M., Smith, N.J.P., Jeffery, D., Long, D., Cameron, T.D.J., Evans, D., Stevenson, A.G., Bulat, J., Ritchie, J.D. 1994. United Kingdom offshore regional report: the geology of the central North Sea. London: HMSO for the British Geological Survey.

Graham, A.G.C., Stoker, M.S., Lonergan, L., Bradwell, T., Stewart, M.A., 2011. In: J. Ehlers, P. L. Gibbard, P. D. Hughes (eds.) The Pleistocene Glaciations of the North Sea Basin. Developments in Quaternary Sciences, Elsevier, 15, pp. 261-278. https://doi.org/10.1016/B978-0-444-53447-7.00021-0.

Haflidason, H., Aarseth, I., Haugen, J., Sejrup, H.P., Løvlieb, R. and Reither, E., 1991. Quaternary stratigraphy of the Draugen area, Mid-Norwegian Shelf. Marine Geology, 101 (1-4), pp. 125-146. https://doi.org/10.1016/00253227(91)90067-E

Haflidason, H., Sejrup, H.P., Klitgaard-Kristensen, D. and Johnsen, S., 1995. Coupled response of the late glacial climatic shifts of northwest Europe reflected in Greenland ice cores: Evidence from the northern North Sea. Geology, 23 (12), pp. 1059-1062. https://doi.org/10.1130/0091-7613(1995)023\%3C1059:CROTLG\%3E2.3.CO;2

Haflidason, H., King, E.L. and Sejrup, H.P., 1998. Late Weichselian and Holocene sediment fluxes of the northern North Sea Margin. Marine Geology, 152, p. 189-215. https://doi.org/10.1016/S0025-3227(98)00071-1

Hjelstuen, B.O., Nygård, A., Sejrup, H.P. and Haflidason, H., 2012. Quaternary denudation of southern Fennoscandia - evidence from the marine realm. Boreas, 41 (3), 379-390. https://doi.org/10.1111/j.15023885.2011.00239.x

Hjelstuen, B.O., Sejrup, H.P., Valvik, E. and Becker, L.W.M., 2018. Evidence of an ice-dammed lake outburst in the North Sea during the last deglaciation. Marine Geology, 402, p.118-130. https://doi.org/10.1016/j.margeo.2017.11.021

Haugwitz, W. R. von and Wong, H.K., 1993. Multiple Pleistocene ice advances into the Skagerrak: A detailed seismic stratigraphy from high resolution seismic profiles. Marine Geology, 111, pp. 189-207. https://doi.org/10.1016/0025-3227(93)90130-N 
Hughes, A.L.C., Gyllencreutz, R., Lohne, Ø.S., Mangerud., J. and Svendsen, J.I., 2016. The last Eurasian ice sheets - a chronological database and time-slice reconstruction, DATED-1. Boreas, 45 (1), pp. 1-45. https://doi.org/10.1111/bor.12142

Jansen E., Sjøholm J., Bleil U., Erichsen J.A., 1990. Neogene and Pleistocene Glaciations in the Northern Hemisphere and Late Miocene-Pliocene Global Ice Volume Fluctuations: Evidence from the Norwegian Sea. In: Bleil U., Thiede J. (eds.) Geological History of the Polar Oceans: Arctic versus Antarctic. NATO ASI Series (Series C: Mathematical and Physical Sciences), vol 308. Springer, Dordrecht. DOI: 10.1007/978-94-009-2029-3_35

Jansen E., Fronval, T., Rack, F. and Channell, E.T., 2000. Pliocene-Pleistocene ice rafting history and cyclicity in the Nordic Seas during the last 3.5 Myr. Paleoceanography and Paleoclimatology, 15 (6), pp. $709-721$. https://doi.org/10.1029/1999PA000435

Kamb B., 2001. Basal zone of the West Antarctic ice streams and its role in lubrication of their rapid motion. In: (eds. R.B. Alley, R.A. Bindschadler) The West Antarctic ice sheet: behaviour and environment, Antarctic Research Series, Washington, DC: American Geophysical Union, 77, pp. 157-201. https://doi.org/10.1029/AR077p0157

King, E., Sejrup, H.P., Haflidason, H., Elverhøi, A. and Aarseth, I., 1996. Quaternary seismic stratigraphy of the North Sea Fan: glacially-fed gravity flow aprons, hemipelagic sedimentation, and submarine sliding. Marine Geology, 130, pp. 293-315. https://doi.org/10.1016/0025-3227(95)00168-9

King, E. C., Hindmarsh, R.C.A. and Stokes, C. R., 2009. Formation of mega-scale glacial lineations observed beneath a West Antarctic ice stream. Nature, 2, pp. 585-588. DOI:10.1038/NGEO581

Klitgaard-Kristensen, D., Sejrup, H.P., Haflidason, H., Johnsen, S and Spurk, M., 1998. A regional 8200 cal. yr BP cooling event in northwest Europe, induced by final stages of the Laurentide ice-sheet deglaciation? Journal of Quaternary Science, 13 (2), pp. 165-169. https://doi.org/10.1002/(SICI)1099-1417(199803/04)13:2\%3C165::AIDJQS365\%3E3.0.CO;2-\%23

Kluijver, M., 1991. Sublittoral hard substrate communities off Helgoland. Helgolander Meeresuntersuchungen, 45, pp. 317-344. 10.1186/s10152-021-00550-3

Kyrke-Smith T.M., Katz, R.F. and Fowler A.C., 2013. Stress balances of ice streams in a vertically integrated, higherorder formulation. Journal of Glaciology, 59, pp. 449-466. https://doi.org/10.3189/2013JoG12J140

Le, T.M.H., Erikson, G.R., Strom, P.J., and Saue, M., 2014. Geological and geotechnical characterization for offshore wind turbine foundations: A case study of the Sheringham Shoal wind farm. Engineering Geology, 177, pp. 40-53. https://doi.org/10.1016/j.enggeo.2014.05.005

Lee, J.R., Busschers, F.S. and Sejrup, H.P., 2012. Pre-Weichselian Quaternary glaciations of the British Isles, The Netherlands, Norway and adjacent marine areas south of $68^{\circ} \mathrm{N}$ : implications for long-term ice sheet development in northern Europe. Quaternary Science Reviews, 44, pp. 213-228. https://doi.org/10.1016/j.quascirev.2010.02.027

Lekens, W.A.H., Haflidason, H., Sejrup, H.P., Nygård. A., Richter, T., Vogt, C. and Frederichs, T., 2009. Quaternary Science Reviews, 28, pp. 469-483. https://doi.org/10.1016/j.quascirev.2008.11.010

Mangerud, J., Gyllencreutz, R. Lohne, $\varnothing$. and Svendsen, J.I., 2011. Glacial History of Norway. In J. Ehlers, P.L. Gibbard and P.D. Hughes (eds.) Developments in Quaternary Science,15, Amsterdam, The Netherlands, 2011, pp. 279-298. https://doi.org/10.1016/B978-0-444-53447-7.00022-2

Milligan, V., 1976. In: R.F., Leggett (ed.): Glacial Till-An Interdisciplinary Study. Royal Society of Canada, Ottawa, pp.269-291.

Morén, B.M., Sejrup, H.P., Hjelstuen, B.O., Borge, M.V., and Schäuble, C., 2018. The last deglaciation of the Norwegian Channel-geomorphology, stratigraphy and radiocarbon dating. Boreas, 47(1), pp. 347-366. https://doi.org/10.1111/bor.12272 
Lien, R., 1983. Iceberg scouring on the Norwegian continental shelf. Continental Shelf Institute Publication, 109, 147 pp. https://doi.org/10.4043/4585-MS

Nesje, A. and Dahl, S.O., 1993. Late glacial and Holocene glacier fluctuations and climate variations in western Norway: A review. Quaternary Science Reviews, 12 (4), pp. 255-261. https://doi.org/10.1016/02773791(93)90081-V

Nesje, A., Kvamme, M., Rye, N. and Løvlie, R., 1991. Holocene glacial and climate history of the Jostedalsbreen region, Western Norway; evidence from lake sediments and terrestrial deposits. Quaternary Science Reviews, 10(1), pp.87-114. https://doi.org/10.1016/0277-3791(91)90032-P

Nygård. A., Sejrup, H.P., Haflidason, H., and Bryn, P., 2005. The glacial North Sea Fan, southern Norwegian Margin: architecture and evolution from the upper continental slope to the deep-sea basin. Marine and Petroleum Geology, 22, pp. 71-84. https://doi.org/10.1016/j.marpetgeo.2004.12.001

Nygård, A., Sejrup, H.P., Haflidason, H., Lekens, W.A.H., Clark, C.D. and Bigg, G.R., 2007. Extreme sediment and ice discharge from marine-based ice streams: New evidence from the North Sea. Geology, 35(5), pp. 395-398. https://doi.org/10.1130/G23364A.1

Ó Cofaigh, C., Evans, J., Dowdeswell, J. A. and Larter, R. D., 2007. Till characteristics, genesis and transport beneath Antarctic paleo-ice streams. Journal of Geophysical Research: Earth Surface, 112, F03006. https://doi.org/10.1029/2006JF000606

Ottesen, D., Dowdeswell, J.A. and Bugge, T., 2014. Morphology, sedimentary infill and depositional environments of the Early Quaternary North Sea Basin $\left(56-62^{\circ} \mathrm{N}\right)$. Marine and Petroleum Geology, 56, pp. 123-146. https://doi.org/10.1016/j.marpetgeo.2014.04.007

Ottesen, D., Stokes, C.R., Bøe, R., Rise, L., Longva, O., Thorsnes, T., Olesen, O. Bugge, T., Lepland, A. and Hestvik, O.B., 2016. Landform assemblages and sedimentary processes along the Norwegian Channel Ice Stream. Sedimentary Geology, 338, pp. 115-137. https://doi.org/10.1016/j.sedgeo.2016.01.024

Radhakrishna, H.S. and Klym, T.W., 1974. Geotechnical properties of a very dense till. Canadian Geotechnical Journal, 11, p. 396-408. https://doi.org/10.1139/t74-040

Reinardy, B. T. I., Larter, R. D., Hillenbrand, C. D., Murray, T., Hiemstra, J. F. and Booth, A.D., 2011. Streaming flow of an Antarctic Peninsula palaeo-ice stream, both by basal sliding and deformation of substrate. Journal of Glaciology, 57, pp. 596-608. doi:10.3189/002214311797409758

Reinardy, B.T.I., Hjelstuen, B.O., Sejrup, H.P., Augedal, H. and Jørstad, A., 2017. Late Pliocene-Pleistocene environments and glacial history of the northern North Sea. Quaternary Science Reviews, 158, pp. 107-126. https://doi.org/10.1016/j.quascirev.2016.12.022

Rise, L., Olesen, O., Rokoengen, K., Ottesen, D., Riis, F., 2004. Mid-Pleistocene ice drainage pattern in the Norwegian Channel imaged by 3D seismic. Quaternary Science Reviews, 23, pp. 2323-2335. https://doi.org/10.1016/j.quascirev.2004.04.005

Rise, L., and Rokoengen, K., 1984. Surficial sediments in the Norwegian sector of the North Sea between $60^{\circ} 30^{\prime}$ and $62^{\circ}$ N. Marine Geology, 58, pp. 287-317. https://doi.org/10.1016/0025-3227(84)90206-8

Rokoengen, K. and Sørensen, S., 1990. Late Jurassic sedimentary bedrock north of Utsira, offshore western. Norway. Norsk Geologisk Tidsskrift, Vol. 70, pp. 61-63. http://pascalfrancis.inist.fr/vibad/index.php?action=getRecordDetail\&idt=19679285

Ruddiman, W.F., Raymo, M. and McIntyre, A., 1986. Matuyama 41,000-year cycles: North Atlantic Ocean and northern hemisphere ice sheets. Earth and Planetary Science Letters, 80 (1-2), pp. 117-129. https://doi.org/10.1016/0012-821X(86)90024-5

Rüther, D.C., Mattingsdal, R., Andreassen, K., Forwick, M. and Husum, K., 2011. Seismic architecture and sedimentology of a major grounding zone system deposited by the Bjørnøyrenna Ice Stream during Late 
Weichselian deglaciation. Quaternary Science Reviews, 30, pp. 2776-2792. https://doi.org/10.1016/j.quascirev.2011.06.011

Sejrup, H.P., Nagy, J. and Brigham-Grette, J., 1989. Foraminiferal stratigraphy and amino acid geochronology of interglacial and glacial sediments in the Norwegian Channel., northern North Sea. Norsk Geologisk Tidsskrift, 69, pp. 111-124.

Sejrup, H.P., Aarseth, I. and Haflidason, H. 1991. The Quaternary succession in the northern North Sea. Marine Geology, 101 (1-4), pp. 103-111.

Sejrup, H.P., Haflidason, H., Aarseth, I., King, E., Forsberg, C.F., Long, D., and Rokoengen, K., 1994. Late Weichselian glaciation history of the northern North Sea. Boreas, 22, pp. 1-13. https://doi.org/10.1111/j.15023885.1994.tb00581.x

Sejrup, H.P., Aarseth, I., Haflidason, H., Løvlie, R., Bratten, Å, Tjøstheim, G, Forsberg, C.F. and Ellingsen, K.L., 1995. Quaternary of the Norwegian Channel: glaciation history and palaeoceanography. Norsk Geologisk Tidsskrift, 75, pp. 65-87.

Sejrup, H.P., King, E., Aarseth, I., Haflidason, H. and Elverhøi, A., 1996. Quaternary erosion and depositional processes: western Norwegian fjords, Norwegian Channel and North Sea Fan. Geological Society of London, 117, pp. 187-202. https://doi.org/10.1144/GSL.SP.1996.117.01.11

Sejrup, H.P., Larsen, E., Landvik, J., King, E.L., Haflidason, H., and Nesje, A., 2000. Quaternary glaciations in southern Fennoscandia: evidence from southwestern Norway and the northern North Sea region. Quaternary Science Reviews, 19, pp. 667-685. https://doi.org/10.1016/S0277-3791(99)00016-5

Sejrup, H.P., Larsen, E., Haflidason, H., Berstad, I.M., Hjelstuen, B.O., Jonsdottir, H.E., King, E.L., Longva, O., Nygård. A., Ottesen, D., Raunholm, S., Rise, L. and Stalsberg, K., 2003. Configuration, history and impact of the Norwegian Channel Ice Stream. Boreas, 32, pp. 18-36. https://doi.org/10.1080/03009480310001029

Sejrup, H.P., Hjelstuen, B.O., Dahlgren, K.I.T., Haflidason, H., Kuijpers, A., Nygård. A., Praeg. D., Stoker, M.S. and Vorren, T.O., 2005. Marine and Petroleum Geology, 22, pp. 1111-1129. https://doi.org/10.1016/j.marpetgeo.2004.09.007

Sejrup, H.P., Clark, C.D. and Hjelstuen, B.O., 2016. Rapid ice sheet retreat triggered by ice stream debuttressing: Evidence from the North Sea. Geology, 44 (5), pp. 355-358. https://doi.org/10.1130/G37652.1

Shackleton, J., Berger, A. and Peltier, W.R., 1990. An alternative astronomical calibration of the lower Pleistocene timescale based on ODP Site 677. Transactions of the Royal Society of Edinburgh: Earth Sciences, 81(4), pp. 251261. doi:10.1017/S0263593300020782

Singh, S. and Murthy, P.S.K., 2016. GNEISSES-Strengths and Mineralogical Compositions. International Journal of Innovative Research in Science, Engineering and Technology, 5(3), pp. 3658-3663.

Tulaczyk S. and Kamb W.B. 2000 Basal mechanics of ice stream B, West Antarctica. 1. Till mechanics. Journal Geophysical Research, 105, pp. 463-481. https://doi.org/10.1029/1999JB900329

Svendsen, J.I., Alexanderson, H., Astakhov, V.I., Demidov, I., Dowdeswell, J.A., Funder, S., Gataullin, V., Henriksen, M., Hjort, C., Houmark-Nielsen, M., Hubberten, H.W., Ingolfsson, O., Jakobsson, M., Kjær. K.H., Larsen, E., Lokrantz., H., Lunkka, J.P., Lyså, A., Mangerud, J., Matiouchkov, A., Murray, A., Moller, P., Niessen, F., Nikolskaya, O., Polyak, L., Saarnisto, M., Siegert, C., Siegert, M.J., Spielhagen, R.F. and Stein, R., 2004. Late Quaternary ice sheet history of northern Eurasia. Quaternary Science Reviews, 23 (11-13), pp. 1229-1271. https://doi.org/10.1016/j.quascirev.2003.12.008

Velenturf APM, Emery AR, Hodgson DM, Barlow NLM, Mohtaj Khorasani AM, Van Alstine J, Peterson EL, Piazolo S and Thorp M, 2021. Geoscience Solutions for Sustainable Offshore Wind Development. Earth Sci. Syst. Soc. 1:10042. doi: $10.3389 /$ esss.2021.10042 
Wenner, E.L., Knott, D.M., van Dolah, R.F. and Burrell Jr., V.G., 1983. Invertebrate communities associated with hard bottom habitats in the South Atlantic Bight. Estuarine, Coastal and Shelf Science, 17 (2), pp. 143-158. https://doi.org/10.1016/0272-7714(83)90059-8

\section{Conference Proceedings}

Bellwald, B., Planke, S., Vadakkepuliyambatta, S., Buenz, S., Batchelor, C., Manton, B., Zastrozhnov, D., Myklebust, R. and Kjølhamar, B., 2020. Quaternary and Neogene Reservoirs of the Norwegian Continental Shelf: Evidence from New 3D Seismic Data. Proceedings of the 82 ${ }^{\text {nd }}$ EAGE Conference and Exhibition, 8-11 June 2020. Amsterdam, The Netherlands. https://doi.org/10.3997/2214-4609.202011459

Forsberg, C.F., Plank, S., Tjelta, T.I., Svano, G., Strout, J.M., and Svensen, H, 2007. Formation Of Pockmarks In The Norwegian Channel. Proceedings of the 6th International Offshore Site Investigation and Geotechnics Conference: Confronting New Challenges and Sharing Knowledge, London, UK, September 2007.

Löhning, T., Kaufmann, K.L. and Groes, J.B., 2021. Drilled Pile Foundations for Offshore Wind Farms. Proceedings of the Thirty-first International Ocean and Polar Engineering Conference, Rhodes, Greece, June 20-25, 2021, pp. 557-563.

Muir Wood, A. and Knight, P., 2013. Site investigation and geotechnical design strategy for offshore wind development. Proceedings of the 18th International Conference on Soil Mechanics and Geotechnical Engineering, Paris 2013, pp. 2375-2378.

\section{Online}

Ellery, G.D. and Comrie, R.J., 2019. Scoping Appropriate Feasibility Level Geophysical and Geotechnical Survey for Offshore Wind - Offsetting Cost against Knowledge Gain. Cathie Group. (Accessed online, 1 September 2020). Available from: https://cathiegroup.com/wp-content/uploads/2019/06/Ellery-GD-Comrie-RJ-ScopingAppropriate-Feasibility-Level-Geophysical.pdf

Hart Energy, 2009. Torpedo pile anchors enter the GoM. (Accessed online, 16 November 2021). Available from: https://www.hartenergy.com/exclusives/torpedo-pile-anchors-enter-gom-17090

Norwegian Ministry of Petroleum and Energy, 2021. Award of acreage and opening of new areas for offshore wind in Norway (Press release No. 028/21). (Accessed online, 30 September 2021). Available from: https://www.regjeringen.no/en/historical-archive/solbergs-government/Ministries/oed/press-

releases/2021/award-of-acreage-and-opening-of-new-areas-for-offshore-wind-in-norway/id2860343/

\section{Data}

Center for International Earth Science Information Network - CIESIN - Columbia University, 2018. Gridded Population of the World, Version 4 (GPWv4): Population Density, Revision 11. Palisades, NY: NASA Socioeconomic Data and Applications Center (SEDAC). (Accessed online, 16 November 2021). Available from: https://sedac.ciesin.columbia.edu/data/set/gpw-v4-population-density-rev11.

https://doi.org/10.7927/H49C6VHW

Ehlers, J., Ehlers, J., Gibbard, P.L. and Hughes, P.D. eds., 2011. Quaternary glaciations-extent and chronology: a closer look (Vol. 15). Elsevier. (Accessed online, 17 November 2021). Available from: https://booksite.elsevier.com/9780444534477/digital_maps.php

NOAA, 2008. ETOPO1 Global Relief Model. (Accessed online, 18 November 2021). Available from: https://www.ngdc.noaa.gov/mgg/global/

Norwegian Mapping Authority, 2018. 5 m Sea Terrain Model. (Accessed online, 22 March 2021). Available from: https://kartkatalog.geonorge.no/metadata/kartverket/sjo-terrengmodeller-dtm-5/13b707ad-a379-4bf0-a707da237d646f44 
Global Wind Atlas, 2021. Wind power density at 100 m: gwa3_250_power-density_100m. (Accessed online, 16 November 2021). Available from: https://data.dtu.dk/articles/dataset/Global_Wind_Atlas_v3/9420803

\section{Reports}

American Bureau of Shipping (2018). Guidance Notes on Design and installation of drag anchors and plate anchors. March 2017 (Updated March 2018). American Bureau of Shipping, ABS Plaza, Houston, USA. Available from:https://ww2.eagle.org/content/dam/eagle/rulesandguides/current/offshore/248_designinstallationdrag_ and_plateanchors/Drag_and_Plate_Anchors_GN_e Mar18.pdf

James, R. and Costa Ros, M., 2015. Floating Offshore Wind: Market and Technology Review Prepared for the Scottish Government. Published in the UK by the Carbon Trust. (Accessed online, 25 June 2021). Available from: https://proddrupalfiles.storage.googleapis.com/documents/resource/public/Floating\%200ffshore\%20Wind\%2 OMarket\%20Technology\%20Review\%20-\%20REPORT.pdf

Vryhof Anchors, 2010. Anchor Manual 2010. Vryhof Anchors BV, P.O. Box 109, 2900 AC Capelle a/d Yssel, The Netherlands. (Accessed online, 15 July 2021). Available from: https://pdf4pro.com/amp/view/the-guide-toanchoring-vryhof-6ac27.html

Wind Europe, 2018. Floating offshore wind energy: A Policy Blueprint for Europe. (Accessed online, 1 July 2021). Available from: https://windeurope.org/wp-content/uploads/files/policy/position-papers/Floating-offshorewind-energy-a-policy-blueprint-for-Europe.pdf 